\title{
Does corporate governance quality affect default risk? The role of growth opportunities and stock liquidity
}

\author{
Searat Ali ${ }^{\mathrm{a}, *}$, Benjamin Liu ${ }^{\mathrm{a}}$, Jen Je Su ${ }^{\mathrm{a}}$ \\ ${ }^{a}$ Department of Accounting, Finance and Economics, Griffith Business School, Griffith University, 170 Kessels \\ Road, Nathan QLD 4111, Australia.
}

This version: April 28, 2018

\begin{abstract}
A series of defaults, a distinctive corporate environment and inconclusive findings in literature make Australia an interesting case in which to investigate the association between corporate governance and default risk. Using a large panel of 1,086 non-financial firms from 2001 to 2013, we find that better governed firms are strongly associated with a lower level of default risk, and that the association is stronger among firms with more growth opportunities. Moreover, empirical evidence supports the role of stock liquidity as a channel of the relationship. Overall these findings have practical implications for the stakeholders in Australia.
\end{abstract}

JEL classification: G01; G33; G34; G38

Keywords: Corporate governance; default risk; growth opportunities; stock liquidity; heterogeneity analysis; channel

\footnotetext{
* Corresponding author. Department of Accounting, Finance and Economics, Griffith Business School, Griffith University, 170 Kessels Road, Nathan QLD 4111, Australia. Tel.: +61 737357295

E-mail addresses: searat.ali@griffithuni.edu.au (S. Ali), b.liu@griffith.edu.au (B. Liu), j.su@griffith.edu.au (J. $\mathrm{Su})$.

¿ We thank Ghon Rhee, Ben Sila, Robert Faff, Philip Brown, Pascal Nguyen, Shams Pathan, Robert Bianchi and Richard Yiu-Ming Chung for providing valuable feedback. We are grateful to an anonymous reviewer and participants for their valuable insights at the Accounting and Finance Association for Australia and New Zealand (AFAANZ) conference in 2016. We also thank Jamshed Iqbal and the participants at the 27th Australasian Finance and Banking Conference (2014) and seminar participants at Griffith University (2014 \& 2016) for their helpful comments and suggestions. We are also grateful to the Risk Management Institute at National University of Singapore for providing the dataset on default risk. We thank SIRCA for assisting us with access to the corporate governance and stock liquidity datasets. We are also grateful to Griffith University Postgraduate Association (GUPSA) and Jennifer Beale for their proofreading service.
} 


\title{
Does corporate governance quality affect default risk? The role of growth opportunities and stock liquidity
}

This version: 28 April 2018

\begin{abstract}
A series of defaults, a distinctive corporate environment and inconclusive findings in literature make Australia an interesting case in which to investigate the association between corporate governance and default risk. Using a large panel of 1,086 non-financial firms from 2001 to 2013, we find that better governed firms are strongly associated with a lower level of default risk, and that the association is stronger among firms with more growth opportunities. Moreover, empirical evidence supports the role of stock liquidity as a channel of the relationship. Overall these findings have practical implications for the stakeholders in Australia.
\end{abstract}

JEL classification: G01; G33; G34; G38

Keywords: Corporate governance; default risk; growth opportunities; stock liquidity; heterogeneity analysis; channel 


\section{Introduction}

Default is among the most disruptive events in the life of a corporation. It is imperative for a firm to avoid default because it brings bankruptcy-filing, legal, and professional costs. It interrupts the supply chain and causes disruptions in productivity (Brogaard et al., 2015). In a case of default, customers may become reluctant to buy products from the defaulted firm; suppliers may tighten credit terms; some current employees may become demotivated due to fear of job insecurity; others may seek employment elsewhere. In addition, default brings mental stress to the proprietor, the entrepreneur, the managers, and their families; it may even destroy lives, ruin the health of its victims and, in a worst-case scenario, push victims to commit suicide (Argenti, 1976). Given these severe consequences of default, it is imperative to explore what determines default risk. In particular, we aim to answer: Does corporate governance affect default risk?

Corporate governance has attracted considerable public attention in recent years around the globe. It has emerged as a hot topic of discussion among researchers and regulators as a result of a number of high profile corporate scandals. For instance, in 2001 the bankruptcy of $\mathrm{HIH}$ Insurance-a major provider of all types of insurance in Australia-was attributed to problematic internal governance such as the improper functioning of the board and the lack of independence of the internal audit committee and the external auditors (Owen, 2003). Similarly, media reports, as well as Australian Government ministers, blamed inefficient management for being the prime reason for the failure of Ansett Australia-Australia's second-largest airline carrier-in 2002 (see Leiper, 2002). Furthermore, in 2001 the bankruptcy of OneTel-once Australia's fourth-largest telecommunication firm, with over 2 million customers and operations in eight countries - is associated with deficiencies in its internal governance, including weaknesses in internal structures and processes, audit quality, and the board's scrutiny of management (see Monem, 2011). These corporate collapses have resulted in the loss of thousands of jobs and have shattered multi billions of dollars in shareholder wealth. ${ }^{1}$ Since these corporate scandals were attributed to problematic internal governance mechanisms, considerable debate initiated to overcome weak corporate governance practices (Kang et al., 2007) resulted in various legislative reforms. In particular, ASX CG Council and related bodies became more vigilant about the risk prevailing in a firm's balance sheet and developed the new governance framework "Principles of Good Corporate Governance and Best Practice Recommendations" in 2003 to deter managers from wealth expropriation and thus restore the confidence of investors (Clarke and Dean, 2007). These governance recommendations focus mainly on controlling risk through monitoring aspects of corporate governance, such as the independence of a board and its subcommittees because board of directors is the 'apex body' of a firm's internal governance system (Fama and Jensen, 1983), and is considered to be the 'first-line of defence' (Hermalin and Weisbach, 1988) for the shareholders against incumbent management. In this study, we

\footnotetext{
${ }^{1}$ For instance, the bankruptcy of HIH insurance caused an enormous loss to both individuals and the community at large, with the total deficit estimated to be between $\$ 3.6$ billion and $\$ 5.3$ billion (Owen, 2003). The bankruptcy of Ansett Australia resulted in the direct job loss of almost 16,000 people and the indirect job loss of approximately 54,880 people (Leiper, 2002).
} 
therefore investigate the role of corporate governance (board structure) as a critical determinant of the default risk.

Studies examining the relationship of corporate governance with ex-post-bankruptcy and ex-post financial distress are aplenty (see e.g., Miglani et al., 2010; Platt and Platt, 2012). Although these studies find a significant role for various governance mechanisms in prediction of bankruptcy and financial distress; but these studies are conducted in an 'expost' setting, which is subject to criticism in terms of non-random sampling design because it imposes substantial limitations on the sample available for investigation (see Balcaen and Ooghe, 2006). ${ }^{2}$ Relatively little effort has been made to empirically investigate the role of corporate governance in the ex-ante default risk (e.g., Chiang et al., 2015; Schultz et al., 2015). Overall, these studies consider individual governance mechanisms (instead of a composite governance index), thus miss out effects from overall governance quality (Henry, 2008). ${ }^{3}$ Notably, the individual governance mechanisms vary from one study to another and sometimes produce contradictory results, making it difficult for investors to decide which governance mechanisms should be considered in developing their investment strategy. ${ }^{4}$ Our study extends this literature by examining the effect of composite governance quality on default risk.

Furthermore, to the best of our knowledge, only two studies investigate the role of individual governance mechanisms in the default risk for Australian firms and find mixed results. One study finds that certain governance mechanisms reduce ex-post financial distress (Miglani et al., 2015) whereas the other study finds that corporate governance does not matter for ex-ante default risk (Schultz et al., 2015). However, both these studies find the irrelevance of board structure with default risk (see section 2 for details). Given these inconclusive findings, which may be caused by using individual governance mechanisms and methodological shortcomings such as small sample size and sample period in the literature, our study is timely and sheds new light on the ongoing literature debate: Does corporate governance (board structure) really affect default risk?

Theoretically, poor corporate governance increases information asymmetries between management and shareholders and maximizes the moral hazard problem where managers can pursue their self-interests (e.g., shirking responsibility and overcompensation), and transfer the wealth of a firm to themselves at the expense of shareholders (Jensen and Meckling, 1976). The moral hazard problem increases the agency risk to the shareholders. The increased

\footnotetext{
${ }^{2}$ Particularly if sampling is done on one-to-one matching criteria, leading to estimation sample which is less representative of the whole population.

${ }^{3}$ Henry (2008) finds no support of individual governance mechanisms in explaining firm value for Australian firms. However, when the individual governance mechanisms are combined together in an index form, there is a significant relationship between the governance score and firm value. He argues that these findings are supportive of the development of a comprehensive code of governance practice, as opposed to the adoption of individual governance practices.

${ }^{4}$ For instance, Miglani et al. (2015) used percentage of independent directors, CEO duality, existence of audit committee, audit opinion, percentage of shares held by directors and block holders. However, Chiang et al, (2015) used board size, board compensation, managerial ownership, director ownership, institutional ownership, and large shareholder ownership.
} 
agency risk decreases the expected value of the future cash flow and increases the volatility of the future cash flow, thus increasing the risk of default in a firm (Ashbaugh-Skaifea et al., 2006). Given these arguments, we hypothesize that poor (better) governed firms should have a lower (higher) level of default risk.

In addition, we explore the two extensions beyond the baseline idea. First, we examine if the governance-default linkage is moderated by degrees of growth opportunities. Specifically, we argue that the effect of corporate governance on default risk may not be uniform across high and low growth firms and that the 'one size fits all' governance practices might be unsuitable. Presumably, information asymmetry is higher for high growth firms since managers are likely to receive private information about the value of future projects that is not readily observable by shareholders. Therefore, high growth firms are associated with higher shareholder/manager agency costs, and are in great need of governance controls (Hutchinson and Gul, 2004). Moreover, Lyandres and Zhdanov (2013) claim that the optimal default strategy of a firm depends on its mix of growth options and assets in place and find that shareholders would be willing to wait longer before default their contractual obligation for firms with valuable investment opportunities than those without such opportunities. Given these evidences, we hypothesize that the inverse relation between corporate governance and default risk should be relatively stronger (in magnitude) for firms with more growth opportunities.

Second, we examine if information asymmetry (measured through stock liquidity) plays the role as a channel between corporate governance and default risk. Better corporate governance mitigates information asymmetry between insiders (e.g., managers) and outsiders (e.g., investors), as well as among outsiders, by improving the informational transparency of a firm (Chung et al., 2010; Prommin et al., 2014). As a result, traders face less adverse selection problems (Glosten and Milgrom, 1985) and are willing to provide more liquidity to stocks of well governed firms. Furthermore, Brogaard et al. (2015) find that default risk decreases with an increase in stock liquidity for the quote-driven US firms. Given these two strands of literature, we posit that corporate governance improves stock liquidity (reduces information asymmetry), and improved stock liquidity in turns reduces default risk.

To test these hypotheses, we take advantage of recently available governance data of Australian firms through the Securities Industry Research Centre of Asia-Pacific (SIRCA) database. We use a large sample of 1,086 non-financial Australian firms (8,950 firm-year observations) over the period from 2001 to 2013, and measure composite corporate governance by following the Horwath report. To measure default risk, we employ two market-based proxies: the Merton (1974) distance to default $(D D)$ and the credit default swap spread $(C D S)$. We measure growth opportunities through the market to book ratio. Finally, we use three proxies of stock liquidity: the time-weighted quoted spread (TWQS), the Amihud illiquidity estimate (AMIHUD), and the turnover-adjusted zero daily volumes $(L M)$. Each of three proxies captures a different liquidity dimension: trading cost, price impact, and immediacy, respectively. 
We have three main results. First, we find that aggregate governance quality is negatively and significantly related to ex-ante default risk. The association survives even after controlling for the firm or industry effect, for a year effect, and for firm characteristics such as profitability, leverage, liquidity, firm size, growth opportunities, and firm age. Via a series of robust checks, we confirm that the findings are insensitive to alternative estimation methods, to endogeneity bias, to alternative proxies of default risk, to individual governance categories, and to additional control variables. From a wider regulatory perspective, our index-based findings are supportive of the development of a comprehensive code of governance practice, as opposed to the adoption of individual governance practices and able to provide a guideline for investors to use composite governance as a benchmark in the selection of stocks that are less likely to face default.

Second, our findings appear to support the hypothesis that the benefit of corporate governance seems to confine to high growth firms only. These findings are robust to alternative proxies for growth opportunities and governance categories. This heterogeneity in the governance-default nexus provides empirical support to the 'comply or explain' governance regime in Australia and suggests that, while designing their corporate governance structure, firms should consider their growth conditions. Our third main result shows the inverse effect of stock liquidity on default risk in a pure order-driven Australian market, and that the interaction effect of corporate governance and stock liquidity on default risk is stronger than the stand-alone partial effect of corporate governance, suggesting that information asymmetry is a channel between corporate governance and default risk. These findings are robust to alternative proxies for stock liquidity, governance categories, and alternative estimation methods. The implication of these findings is that firms with low stock liquidity should strive for high governance standards if they are to avoid future defaults.

The main contributions of our study to the literature are threefold. First, we contribute to the literature on corporate governance and default risk (e.g., Chiang et al., 2015; Schultz et al., 2015). As far as could be ascertained, this is the first study to show that composite internal corporate governance is relevant to default risk in the Australian context, even when a potential endogeneity bias is considered. Second, we contribute to the growing governance literature that argues 'one size does not fit all' (e.g., Coles et al., 2008) by providing a new insight that the relationship between corporate governance and default risk depends on growth opportunities. Third, while documenting that corporate governance interacts with information asymmetry to reduce default risk, we complement the two streams of literature: (1) corporate finance (i.e., corporate governance) and market microstructure (i.e., stock liquidity) (e.g., Chung et al., 2010), and (2) market microstructure (i.e., stock liquidity) and asset pricing (i.e., default risk) (e.g., Brogaard et al., 2015).

We also contribute to the literature in terms of methodology. First, unlike prior studies on corporate governance and default risk in Australia (Miglani et al., 2015; Schultz et al., 2015), the sample firms in our study come from all non-financial industries and ages, and are heterogeneous in size and profitability. The extended dataset allows us to generalize results to small, medium, and large Australian firms. Second, extant literature is limited to the period 
prior to the global financial crisis (GFC) i.e., 2008-2009; ${ }^{5}$ thus, the finding might not be directly applicable to the post-GFC (2010 onwards) conditions. Third, we provide additional evidence for the usefulness of the Horwath report by linking it to the default risk. Prior studies measuring corporate governance through the Horwath report either are cross-sectional or have linked it to corporate activities other than default risk, such as information disclosure (Beekes et al., 2015), and stock liquidity (Ali et al., 2016). Moreover, given some limitations of the Horwath report (see section 4.3 for details); we simplify the Horwath report by excluding the subjective criteria and by using an equally weighted scoring methodology, as well as, we extend the Horwath report to both cross-sectional (including small and medium firms) and time-series (including 2009 to 2013) dimensions.

The remainder of the paper is structured as follows. Section 2 provides the reasons for selecting Australia as a case study. Section 3 presents the literature review and hypotheses development. Section 4 describes the data, variables, estimation models, and econometric methods, and provides summary statistics. Section 5 discusses the main empirical results for the relationship between corporate governance and default risk. Section 6 discusses the results on the role of growth opportunities in the relationship between corporate governance and default risk. Section 7 provides the results on stock liquidity and the impact of corporate governance on default risk. Section 8 documents the additional analysis of the relationship between corporate governance and default risk. Section 9 concludes the paper.

\section{Motivation: Why Australia?}

Australia is an interesting case for examining the empirical relationship between corporate governance and default risk because of two key factors: the distinctive corporate environment, and the contradictory findings in the literature. First, findings from other countries may not directly apply to the Australian market because of the different corporate environment-Less stringent governance, high agency costs, weak market for control, high ownership concentration and low litigation risk - that has a significant influence on the internal governance practices of firms (e.g., Méndez et al., 2015; Monem, 2013). For instance, compared to the US, where corporate governance is mandatory, Australian firms are subject to a 'comply or explain' regime; that is, a firm is required to disclose a reason if it does not comply with any governance recommendation. Given such a free environment, we expect a larger variation in the corporate governance practices of Australian firms, which may influence default risk differently. Furthermore, Australian firms experience higher agency cost than the US firms. In such environment, the role of corporate governance as a monitoring mechanism is important in reducing agency costs (Henry, 2010). Moreover, Australia has a weak market for corporate control (i.e., threat of takeover), compared to the US, which makes the internal governance mechanisms more important for Australian firms to

\footnotetext{
${ }^{5}$ Sample periods of 1998 to 2009 (Chiang et al., 2015), 2001 to 2007 (Switzer and Wang, 2013; Schultz et al., 2015), 1999 to 2003 (Miglani et al., 2015).
} 
discipline poorly performing managers. In addition, Australian firms have a much higher ownership concentration than the US firms (La Porta et al., 1998). Since ownership concentration may act as a substitute for the internal monitoring mechanisms (e.g., independent directors and audit committee), governance practices are likely to vary between Australian and the US firms. Finally, the Australian legal environment discourages litigation against directors whereas the US legal environment is hospitable to securities lawsuits against directors. This suggests a higher level of litigation risk in the US than in Australia (Monem, 2013). Since litigation risk could increase the directors' and auditors' supervisory roles, results from the US studies might be difficult to extrapolate to Australia. These differences motivate us to investigate the role of corporate governance in determining default risk for Australian firms.

Second, inconclusive findings in the scarce governance-default literature provide another reason for Australia as an interesting case. To the best of our knowledge, only two studies investigate the role of individual governance mechanisms in the default risk of Australian firms (see e.g., Miglani et al., 2015; Schultz et al., 2015). Of these, the study by Schultz et al. (2015) is related to our study since it is conducted in an ex-ante setting. Specifically, they examine the relationship between individual governance mechanisms (board structure, remuneration and ownership variables) and default risk (Merton distance to default) for 222 healthy firms (932 firm year observations) during the period from 2001 to 2007. Surprisingly, their pooled OLS result shows that the proportion of non-executive directors is associated with the increase in the probability of the default. Moreover, these results disappear in the dynamic panel data setting. Overall, they conclude that the relationship between corporate governance and default risk is spurious, due to an endogeneity bias. The findings from their study, however, should be interpreted carefully for a number of reasons. First, their study does not report the correlation analysis and some of the individual governance variables included in the regression are highly correlated, might have caused the results to be inconclusive. Second, they consider only the large firms; therefore, the findings may not be generalizable to small and medium firms. Second, most of the large firms may have similar governance mechanisms and are financially healthy, so the probability of default is near to zero, and thus there is little or no variation in both independent (i.e., governance) and dependent (i.e., default risk) variables, leading to insignificant association. ${ }^{6}$ Finally, their study does not consider the GFC (2008-2009) and post-GFC (2010 onward) periods, so the recent market conditions is ignored.

Miglani et al. (2015) investigate the association between individual governance mechanisms and financial distress in an ex-post setting during the period of 1999 to 2003. Based on a sample of 171 financially distressed and 106 healthy firms, the authors suggest that the adoption of certain governance mechanisms is beneficial for firms to reduce financial distress, even when endogeneity is considered. For instance, they find that the existence of a separate audit committee is associated with lower chances of financial distress. However, they find no significant association of board independence and CEO duality with financial distress. The inconclusive findings, however, are subject to several limitations. First, an ex-

\footnotetext{
${ }^{6}$ When we restrict the sample to top 200 firms from 2001 to 2007, we also find no evidence of the effect of governance on default risk. Hence, large firms are very similar in terms of their governance quality and governance quality is very sticky variable. The inconclusive evidence may possibly be due to the sample used in the prior studies.
} 
post approach is widely criticized in literature due to sample design. Second, most of the financially distressed firms are small in size, and their findings might not be generalizable to medium and large firms. Third, their results are based on the voluntary governance environment, thus the findings might not be generalizable to the time period after the governance reforms (2003). Likewise, using a cross-sectional sample of 38 Australian firms in 2004, James-Overheu and Cotter (2009) find that corporate governance index does not affect default risk, as measured through credit rating. These inconclusive findings in Australia are inconsistent with the spirit of the ASX corporate governance recommendations (i.e., higher proportion of independent directors on the board), and therefore, demand further investigation: Does corporate governance really affect default risk? To overcome the methodological concerns, we have used composite governance index for 1086 Australian firms (8950 firm year observations) over the period from 2001 to 2013 covering pre reform, post reform, during GFC, and post GFC periods. Moreover, we include two proxies of exante default risk proxies: Merton distance to default and CDS spread for the robustness purpose. Finally, we address endogeneity concern using 2SLS with two instruments (industry average and industry-location average) which has not been included in the prior Australian studies on governance and default.

\section{Related literature and hypotheses development}

\subsection{Corporate governance quality and default risk}

The likelihood of default faced by a firm depends upon whether the firm's future cash flows are sufficient to cover both its debt service costs (interest payments) and the principal amount. In general, the likelihood of default increases when a firm experiences a downward shift of its average future cash flows or when the future cash flows become more volatile.

Under the agency theory framework of Jensen and Meckling (1976), the separation of ownership and control in the modern corporation raises an information asymmetry problem between management and shareholders; that is, the manager has information that shareholders do not have. Information asymmetry creates a moral hazard problem where managers have an incentive to pursue their own interests and transfer the firm's wealth to themselves at the expense of external stakeholders (Switzer and Wang, 2013). Self-interested and opportunistic managerial behavior can include shirking responsibility, overcompensation, consumption of perquisites and empire building, which increases the agency risk to the shareholders. The increased agency risk decreases the expected value of future cash flows to the firm and its shareholders, and increases the volatility of cash flows; thus, it increases the risk of default in a firm (Ashbaugh-Skaifea et al., 2006). We therefore hypothesize that corporate governance influences the default risk of a firm by controlling the agency cost that arises from the agency conflict between management and shareholders (the "management disciplining' hypothesis). In firms with better corporate governance, managers are subject to close monitoring, which can reduce information asymmetry and enhance the effectiveness of managerial decision making. Effective managerial decisions are more likely to increase 
expected cash flows and to decrease the volatility of cash flows, and thus decrease the chances of default.

The governance metrics in our study cover four dimensions of corporate governance (board structure, and audit, nomination and remuneration committees), consisting of a total of 17 governance factors. The proportion of independent directors is one of the key features of a board's structure. The ASX CG Council (2003), in Principle 2.1, recommends firms' boards to have a higher proportion of non-executive independent directors (outside directors). Outside directors are more effective than executive directors (inside directors) in monitoring and controlling the opportunistic behavior of managers (CEOs), and in reducing agency problems (Fama and Jensen, 1983). A board dominated by inside directors is relatively weak in monitoring the performance of the CEO, as the career path of inside directors can be influenced by their CEO; a board dominated by outside directors is expected to be better in monitoring and replacing a poorly performing CEO as the future income of outside directors is less reliant on the CEO (Weisbach, 1988). Therefore, in the presence of a higher proportion of independent directors, a CEO may become sensitive to underperformance and thus make more effective decisions, resulting in reduced default risk. Interestingly, contrary to this theoretical argument, Australian studies document the insignificant role of independent directors in mitigating probability of default and financial distress (Miglani et al., 2015; Schultz et al., 2015).

CEO duality, another important aspect of the board structure, has received much attention from researchers and regulators. The ASX CG Council (2003) recommends that firms separate the roles of CEO and chair of the board (see principle 2.3), and that an independent director should chair the board (see principle 2.2). Agency theory argues that one individual should not perform the roles of board chair and CEO simultaneously (Zahra and Pearce, 1989). CEO duality is considered as power hoarding which may lead to default risk in a firm. However, the empirical evidence of the relationship between CEO duality and survival of a firm is inconclusive (Miglani et al., 2015; Schultz et al., 2015; Switzer and Wang, 2013).

The ASX CG Council (2003) states, in Principle 2, that a firm should have a committed board that adequately discharges its responsibilities and duties. Since board commitment is not directly observable, the frequency of board meetings (i.e., the number of times the board meets in a year) can be used as a proxy for board commitment. With more frequent board meetings, the board is likely to have richer information about the firm's operating environment. This improves the board's ability to effectively exercise its monitoring role (Rutherford and Buchholtz, 2007), which is beneficial for eliminating information asymmetry problem and this improves the chances of a firm's survival.

The ASX CG Council (2003), in principles 2.4, 4.2, and 9.2, recommends that firms establish board subcommittees: audit, nomination, and remuneration. The specific responsibilities of these committees may assist in remedying any poor attendance of directors (Harrison, 1987). Upadhyay et al. (2014) argue that board committees improve the 
observability of the performance of individual directors and also reduce coordination and communication problems. The role of the audit committee has received most academic attention. It is regarded as an important internal governance mechanism that assists in the reduction of information asymmetry between shareholders and management (Adams and Ferreira, 2007). Its interaction with external auditors assists the board to ensure that the financial statements represent a true and fair view of the firm's financial condition (Platt and Platt, 2012). Klein (2002) argues that an audit committee composed of independent directors improves board effectiveness in monitoring management. Miglani et al. (2015) show that the presence of audit committee in a firm reduces the chances of default. In addition, Platt and Platt (2012) find that the number of independent directors on the audit and remuneration committees of failed firms is fewer than that of non-failed firms. Overall, this evidence suggests that the existence and quality of board subcommittees play an effective monitoring role and are thus likely to reduce the default risk of firms.

Following from the above discussion, we hypothesize that:

H1. All else being equal, better corporate governance (as measured through the quality of board and its subcommittees) reduces the default risk.

\subsection{Growth opportunities, corporate governance quality and default risk}

The most comprehensive review of the internal governance mechanisms of listed Australian firms, the "Principles of Good Corporate Governance and Best Practice Recommendations", was introduced by the ASX CG Council in March 2003 and subsequently revised in 2007, 2010 and 2014. The review initially proposes ten principles and contains 28 recommendations applicable to the governance practices of listed firms in Australia. ASX listing rule 4.10.3 [formerly ASX listing rule 3c (3) (i)] requires listed firms to disclose their compliance with the CG reforms in their annual report, beginning with the first financial reporting year after January 1, 2003. The ASX CG Council, however, recognizes that:

...Different entities may legitimately adopt different governance practices, based on a range of factors, including their size, complexity, history and corporate culture. For that reason, the Principles and Recommendations are not mandatory and do not seek to prescribe the corporate governance practices that a listed entity must adopt.

This indicates that best practice recommendations acknowledge the inappropriateness of the 'one size fits all' approach, that is, firms may adopt particular corporate control systems based on certain internal characteristics and the organizational environment. In this study, we focus on a firm's growth opportunity as an organizational environmental factor and posit that the predicted negative association between corporate governance and default risk is dependent on the growth opportunity. Importantly, none of the prior studies investigate the heterogeneity in the governance-default nexus based on growth opportunity. In general, the growth opportunity is chosen as a moderator between governance-default linkage because high growth firms are expected to experience higher information asymmetry and higher 
monitoring costs (e.g., Hutchinson and Gul, 2004; Lasfer, 2002) that may affect the governance choices of such firms and thus affect the default risk in a different way.

Agency theory suggests that corporate controls (e.g., independent directors) are linked to information asymmetry. However, the level of information asymmetry is not the same for all firms. As a result, it is not likely that corporate controls reduce default risk for all firms. This suggests that corporate controls are more important for firms that may suffer from high information asymmetry. The incidence of information asymmetry is higher for growth firms because managers may have private information about the value of future projects and hence their actions are not readily observed by shareholders. Therefore, high growth firms are associated with higher shareholder/manager agency costs, and are in great need for corporate controls (Hutchinson and Gul, 2004).

Prior literature divides firm value into two components (Myers, 1977): the assets in place, whose value does not depend on the future investment opportunities of the firm, and the growth options, whose value depends on the future discretionary investment decisions. The observability of managerial actions decreases as investment opportunities increase (Smith and Watts, 1992), because the value of the growth options depends on further managerial discretionary expenditures such as maintenance and replacement of existing assets, new product lines and capacity expansion projects (Gaver and Gaver, 1993). This suggests that monitoring management is more difficult (less difficult) for firms with more growth opportunities (fewer growth opportunities). Accordingly, a stream of literature suggests that the cost of monitoring managers is more in high growth firms, due to large information acquisition and communication costs; therefore, firms with more growth opportunities require a lower proportion of independent directors (see e.g., Chen, 2015; Coles et al., 2008; Linck et al., 2008; Monem, 2013).

The question of interest is does the independent governance structure bring more benefit than monitoring cost to the shareholders of high growth firms? In this vein, Lyandres and Zhdanov (2013) claim that the optimal default strategy of a firm depends on its growth opportunities (i.e., mix of growth options and assets in place). They argue that default is costly for the shareholders of high growth firms because, in the case of default, shareholders not only surrender the right to the profit flow generated by the assets in place but they also abandon the right to exercise the investment option in the future. Accordingly, they find that the shareholders of a firm with valuable investment opportunities are willing to wait longer before defaulting on their contractual debt obligations than shareholders of an otherwise identical firm without such investment opportunities. Therefore, shareholders of the high growth firm may favour certain governance mechanisms that help such firm to survive.

Given such evidence, we argue that the benefit of valuable growth opportunities may outweigh the cost of monitoring managerial behavior in high growth firms. Therefore, despite of the high monitoring cost associated with independent directors in high growth firms, the shareholders in such firms are willing to employ corporate controls to curtail the chances of the default, and thus keep the rights to the profit flow generated by the assets in place and to exercise the investment option in the future. Therefore, we develop the following hypothesis: 
H2. All else being equal, the inverse relation between corporate governance and default risk is stronger for firms with more growth opportunities than for firms with fewer growth opportunities.

\subsection{Stock liquidity, corporate governance quality and default risk}

We argue in $\mathrm{H} 1$ that corporate governance quality (board and its subcommittees) may reduce information asymmetry between management and shareholders, and thus reduce default risk. In this section, we further elaborate on this channel by considering stock liquidity as a proxy of information asymmetry. Specifically, we discuss two important questions: how corporate governance affects stock liquidity, and how stock liquidity affects default risk. Overall, we argue that if corporate governance is related to stock liquidity and stock liquidity is related to default risk; then it seems appropriate to assume that corporate governance may interact with stock liquidity to reduce default risk.

Better corporate governance imposes more monitoring on managers and, therefore, prevents opportunistic managers from concealing and distorting information. Therefore, better corporate governance improves information environment of a firm and mitigates information asymmetry between insiders (e.g., managers) and outsiders (e.g., investors), as well as among outsiders. When information asymmetry is less severe, traders face less adverse selection problems (Glosten and Milgrom, 1985); hence, they provide more liquidity to stocks of well governed firms. Several empirical studies provide support for this theoretical argument by showing that firms with better corporate governance have improved information environment (Beekes et al., 2015; Haß et al., 2014) and have improved stock liquidity (Chung et al., 2010; Prommin et al., 2014).

We discuss two views based on which stock liquidity may reduce default risk. The first is related to 'reliance on debt'; the second is related to 'repayment of debt'. According to the first view, stock liquidity should mitigate default risk by reducing the reliance of a firm on debt financing. In particular, stock liquidity reduces the cost of equity, thus making the equity a cheaper source of finance. The firms with more equity finance are less concerned about the debt repayment and thus have lower default risk. In line with this argument, a number of empirical studies show that the firms with more liquid stock have a lower cost of equity and lower leverage (e.g., Lipson and Mortal, 2009), and the firms with lower leverage have a lower default risk. Collett and Hrasky (2005) examine the relationship between the voluntary disclosure of information about corporate governance practices and the intention to raise external finance using the data of 75 Australian companies in 1994. They find voluntary disclosure of corporate governance information is positively associated with the intention to raise equity capital, but not with the intention to raise debt capital. These findings suggest that better governed firms have more equity in the capital structure and are thus less likely to default. According to the second view, stock liquidity may also mitigate default risk by increasing the ability of a firm to raise external finance in repaying debt at the time of need. Since firms require financial resources to repay their debt, it seems appropriate to assume that default risk is higher for the firms that face a severe discount in selling their assets in an 
illiquid market. Therefore, if a firm with a debt in its capital structure faces deteriorating funding liquidity (availability of internal cash); its ability to repay debt should heavily depend on stock liquidity. In other words, when a firm needs external funds to repay debt, stock market liquidity is a critical factor in determining the firm's survivability. Consistent with these arguments, Frino et al. (2007) show that the bid-ask spread (a measure of stock liquidity) of defaulted firms widens substantially up to seven months prior to failure, indicating the likelihood of significant information asymmetries across market participants (greater illiquidity) in the defaulted firms. Likewise, Brogaard et al. (2015) find that default risk decreases with an increase in stock liquidity.

Bringing the two streams of literature together-first, the corporate governance and information asymmetry (stock liquidity); second, the stock liquidity and default risk-we therefore develop the following hypothesis:

H3. All else being equal, the corporate governance's reduction in default risk is strengthened via the channel of information asymmetry (improved stock liquidity).

\section{Data, variables and econometric methods}

\subsection{Sample and data}

The initial dataset of 13,500 firm years consists of all the Australian listed firms whose corporate governance data are available in SIRCA for the period from 2001 to 2013. The sample period is important since it includes the ASX CG reforms (2003) and the GFC (2008). Consistent with the prior literature on corporate governance and default risk, and for better comparison of results with prior studies (e.g., Chiang et al., 2015; Schultz et al., 2015), we exclude financial firms from the sample. Further, financial firms have unique business nature and financial characteristics; that is, substantially higher leverage that may significantly affect their corporate governance choices and default risk, thus rendering them different from the other firms in the sample. We obtain default risk data from the Risk Management Institute at the National University of Singapore, ${ }^{7}$ data for the calculation of stock liquidity from SIRCA, and firm characteristics data from Morningstar DatAnalysis Premium databases. The inclusion of each firm-year observation in the sample is conditional on the availability of corporate governance, default risk, stock liquidity, and firm-specific data. The final sample comprises 8851 observations on 1086 non-financial firms ${ }^{8}$ from all size groups (small, medium and large). To eliminate any undue influence of extreme values in the data, possibly

\footnotetext{
${ }^{7}$ This database covers over 60,000 public firms in 106 economies in Asia-Pacific, Europe, Americas, Middle East and Africa. It was launched in 2009 to act as a not-for-profit counterbalancing force to the for-profit credit rating agencies (Duan and Van Laere, 2012).

${ }^{8}$ The highest number of observations is from Materials $(32.78 \%)$, followed by Industrials (15.54\%), Consumer Discretionary (13.31\%) and Energy (13.12\%). The remaining sectors (Consumer Staples, Health Care, Information Technology, Utilities and Telecommunication Services) each contribute less than $10 \%$ to the sample.
} 
due to spurious outliers, all continuous variables are winsorized to the 5th and 95th percentiles.

\subsection{Measuring default risk}

The dependent variable in our study is the default risk (DEFAULT). Since the seminal work of Beaver (1966), a number of accounting and market-based default risk models have been developed in the literature. The validity of accounting-based models has been questioned, due to the backward-looking nature of the financial statement through which these models are derived. On the other hand, market-based models using the option pricing approach developed by Black and Scholes (1973) and Merton (1974) provide an appealing alternative to the prediction of default risk conditions of listed firms. Such a methodological approach overcomes the criticisms of accounting-based models through the forward-looking nature of market data. Market data reflect expectations of a firm's future cash flows, and hence should be more appropriate for prediction purposes. Another prevalent feature of such models is their provision of a 'finer' volatility assessment that aids in predicting the risk of default. Empirical studies such as Gharghori et al. (2006) and Hillegeist et al. (2004) find that Merton (1974) market-based model is superior to their accounting counterparts in predicting default in the Australian and US context, respectively. We therefore use the market-based Merton (1974) distance to default $(D D)$ in gauging default risk (see Appendix A: General procedure to calculate $D D)^{9}{ }^{9}$

We also check the robustness of the results by using market-based credit default swap spread $(C D S)$ to proxy the pricing of default risk. $C D S$ are credit derivatives that allow the transfer of the firm's default risk between two agents for a predetermined time period. In a typical $C D S$ contract, the protection seller offers the protection buyer insurance against the default of an underlying bond issued by a certain company (the reference entity). In an event of default by the reference entity, the seller commits to buy the bond for a price equal to its face value from the protection buyer. ${ }^{10}$ In exchange for the insurance, the buyer pays a quarterly premium, called the $C D S$ spread, quoted as an annualized percentage of the notional value insured. Therefore, by definition, the $C D S$ is the pricing of the default risk. The higher the default risk of the reference entity, the higher is the CDS. Tang and Yan (2010) find that the $C D S$ captures the major portion of the firm level determinants of default risk. Thus, it should serve as an alternative measure of a firm's default risk conditions.

\subsection{Measuring corporate governance quality}

The key independent variable in our study is corporate governance quality (CGQ). We construct a $C G$ index by generally following the methodology of the Horwath report to

\footnotetext{
${ }^{9} \mathrm{We}$ also note some limitations of the market-based models. In particular, it is difficult to measure default risk of a firm who is not trading on the stock market. Moreover, to accurately predict default risk, market-based models require the market transparency and liquidity. Importantly, market-based models have a number of assumptions that in practice may not hold. For example, the DD assumes that asset values follow a lognormal process, which will not capture extreme events adequately.

${ }^{10}$ In practice, the terms of the $C D S$ could involve physical delivery of the defaulted bond or cash settlement.
} 
capture the CGQ for each of the considered firms. This report pays special attention to the aspects that have been viewed as important in governance best-practice codes in Australia and elsewhere (USA Blue Ribbon Committee Report 1999 [The Business Lawyer 1999]; Australian Securities Exchange (ASX) Principles of Good Governance and Best Practice Recommendations 2003 [ASX CG Council 2003]; the Organization for Economic Cooperation and Development (OECD) Report 2004). Unlike the well-renowned US based Gompers et al. (2003) governance index (i.e., G-index), which focuses on the resistance of firms to external control mechanisms, the Horwath report places emphasis on the quality of a firm's internal structures and processes. The Horwath report provides composite ratings based on six categories; namely, (1) board structure, (2) audit committee, (3) nomination committee, (4) remuneration committee, (5) external auditor independence, and (6) codes of conduct and other policy disclosures (see Appendix B: Horwath corporate governance report, 2008). ${ }^{11}$

Multiple aspects may limit the generalizability of the findings obtained through the Horwath report. First, the Horwath report includes the top 250 firms each year; thus, the findings may not be generalizable to medium and small firms. Second, the report is available up to 2008; therefore, missing out market developments, particularly after the GFC. Third, full details of the Horwath rating system are proprietary and confidential, so we are unable to make any comments on the assignment of ranking beyond the information given in the reports. In addition, two of the six categories in the Horwath report are subjective. This may limit the implications of the findings for investors because they may not be able to replicate the entire Horwath ratings. Fourth, the Horwath report does not provide the sub-category scores, so it is not possible to explore which governance category influence default risk.

We address these issues by collecting an extended CG dataset across both cross-section (small, medium, and large firms) and time-series (2001-2013) on the objective Horwath categories containing 17 governance criteria. To construct the $C G$ index, we use equally weighted scoring methodology that has been used by extant corporate governance literature (e.g., Gompers et al., 2003). We assign the value 1 if a firm meets the particular criteria and 0 otherwise. For instance, if the majority of directors in a firm are independent we assign 1, and otherwise 0 . These individual values are then aggregated to construct a composite CG index, which ranges from 0 to 17 where 0 indicates the 'worst' governance and 17 indicates the 'best' governance. Each governance category i.e., board, audit, nomination and remuneration quality is the aggregate of its respective individual criteria (see Appendix C: Simplified corporate governance index).

\subsection{Measuring growth opportunities}

Following Lyandres and Zhdanov (2013), we measure firm's growth opportunities using the market-to-book ratio $(M T B)$; that is, the market value of an equity divided by its book value. The market value is defined as the product of the number of common shares

\footnotetext{
${ }^{11}$ Categories 1-4 are based on objective criteria and categories 5-6 are based on subjective criteria. More details can be found at http://www.ecgi.org/codes/documents/horwath_cg_02.pdf
} 
outstanding and the financial-year-end share price. Higher $M T B$ implies higher growth opportunities. To check the robustness of the results, we use Tobin's $Q$ as an alternative proxy for growth opportunities (Hutchinson and Gul, 2004). It is the market value of assets divided by book value of assets. The higher the Tobin's $Q$, the higher is the growth opportunity.

\subsection{Measuring stock liquidity}

Stock liquidity is considered a 'slippery and elusive concept' (Kyle, 1985: p. 1316) due to number of transactional properties of the market, including tightness (trading cost), depth (price impact) and resiliency. Tightness represents the cost of turning around a position over a short period of time. Depth refers to the ability of the market to absorb a large quantity of trade without having a large price impact. Resiliency is the speed with which the prices return to equilibrium after a large trade. ${ }^{12}$ Black (1971) suggests another stock liquidity dimension, immediacy, which represents the trading speed, i.e., the speed with which buy or sell orders can be executed. Prior stock liquidity research normally does not rely on one single measure of stock liquidity because each measure proxies different dimensions and has its own limitations (Goyenko et al., 2009); therefore, we use three proxies for stock liquidity (as a measure of information asymmetry) that capture trading cost, price impact and immediacy dimensions. In particular, we use a time-weighted quoted spread (TWQS) capturing trading cost dimension, the Amihud illiquidity estimate (AMIHUD) capturing price impact dimension, and the turnover-adjusted zero daily volumes $(L M)$ capturing immediacy dimension. Higher TWQS, AMIHUD, and $L M$ indicate lower stock liquidity. However, we convert each of them into a dummy variable coded 1 (indicating higher stock liquidity) if the value is below the sample median, otherwise zero (indicating lower stock liquidity).

TWQS, a high frequency proxy, is a widely used measure of stock liquidity in the microstructure literature and is considered as a direct measure of trading cost. The bid-ask spread widens when information asymmetry is high because, in such circumstances, uninformed traders shift orders away from the market and decrease the likelihood of trading with informed traders. We measure TWQS as an average of daily ratio between the timeweighted bid-ask spread (TWBAS) and the time-weighted mid-point price (TWMPP) in a financial year (Aitken and Frino, 1996; Chang et al., 2008).

$$
\begin{aligned}
& T W Q S_{i t}=\frac{1}{D_{i t}} \sum_{d=1}^{D_{i y}} \frac{T W B A S_{i t d}}{T W M P P_{i t d}} \\
& T W B A S_{i t d}=\frac{(A s k-B i d) \times \text { Time }_{1}+(\text { Ask }- \text { Bid }) \times \text { Time }_{2}+\cdots+(A s k-B i d) \times \text { Time }_{n}}{\text { Time }_{1}+\text { Time }_{2}+\cdots+\text { Time }_{n}} \\
& T W M P P_{i t d}=\frac{\frac{(A s k+B i d)}{2} \times \text { Time }_{1}+\frac{(A s k+B i d)}{2} \times \text { Time }_{2}+\cdots+\frac{(A s k+B i d)}{2} \times \text { Time }_{n}}{\text { Time }_{1}+\text { Time }_{2}+\cdots+\text { Time }_{n}}
\end{aligned}
$$

\footnotetext{
${ }^{12}$ Chai et al. (2010) find that the return reversal effect is small in the Australian market due to the absence of dealers. Therefore, we do not test this dimension of stock liquidity in this study.
} 
where TWBAS ${ }_{i t d}$ is the time-weighted bid-ask spread of firm $i$ on day $d$ of year $t$, $T W M P P_{i t d}$ is the time-weighted mid-point price of firm $i$ on day $d$ of year $t, D_{i t}$ is the number of days with available data for firm $i$ in year $t$. Ask and Bid are the best available ask and bid prices on the limit order book; Time $_{n}$ represents the time period that the bid ask spread remained in existence. The higher TWQS indicates lower stock liquidity.

Amihud (2002) illiquidity estimate (AMIHUD), a low frequency proxy, is used to measure the daily price impact of the order flow-the premium that a buyer pays or the discount that a seller concedes when executing a market order-that results from inventory and adverse selection costs. Prior studies such as Huang and Stoll (1996) on informed trading claim that price impact of trade captures information asymmetry as trade conveys private information. A large trade may attract other traders because there is a possibility that trade is information motivated. For example, a large sale may signal bad news while a large purchase may signal good news. A number of empirical studies show that ILLIQ is a reliable measure stock liquidity (Goyenko et al., 2009). It is measured as the daily ratio of absolute stock return to trading volume in Australian dollars, averaged over a number of trading days in the financial year, i.e., how much absolute stock price changes with one dollar of trading volume.

$I L L I Q_{i t}=\frac{1}{D_{i t}} \sum_{d=1}^{D_{i t}} \frac{\left|R_{i d t}\right|}{\operatorname{VOLD} D_{i d t}}$

where $\left|R_{\text {idt }}\right|$ is the absolute stock return of firm $i$ on day $d$ of year $t, V O L D_{i d t}$ is the trading volume of firm $i$ on day $d$ of year $t$, and $D_{i y}$ is the number of days with available data for firm $i$ in year $t$. The higher the ILLIQ, the lower is the stock liquidity.

Liu (2006) proposes a turnover-adjusted zero daily volume $(L M)$ as a new measure of stock liquidity. Although LM captures multiple dimensions of liquidity, it places a particular focus on immediacy. It is measured as:

$L M_{i t}=\left[N o Z V_{i t}+\frac{\left.1 / \text { turnover }_{i t}\right)}{\text { Deflator }}\right] X \frac{252}{\text { NoTD }_{t}}$

where $\operatorname{NoZV}_{i t}$ is the number of zero daily trading volumes for firm $i$ in year $t$; turnover $_{i, t}$ is the stock turnover for firm $i$ in year $t ; N o T D_{t}$ is the total number of trading days in year $t$; and the deflator is set to 480,000 as suggested in Liu (2006). Multiplication by the factor $\frac{252}{\text { NoTD }_{t}}$ standardizes the number of trading days in a year to 252 and therefore makes LM comparable over time. The higher the $L M$, the lower is the stock liquidity. The NoZV component of LM is an indicator of illiquidity-the higher the number of days with zero trading volume, the less frequent the trade and, therefore, the less liquid the stock. It reflects the trade continuity and potential delay in trade execution (Liu, 2006).

\subsection{Control variables}

We also include several control variables in the regression models from prior literature to control for other effects on default risk, such as return on assets (ROA), liquidity ratio 
(LIQUID), leverage (TLTA), firm size $(\operatorname{Ln}(T A))$, firm age, $(\operatorname{Ln}(A G E))$, year effects $(Y R)$, and industry effects $(I N D)$. The definition of each variable is in Table 1.

\section{[Insert Table 1 here]}

\subsection{Empirical models and estimation methods}

To test the inverse effect of corporate governance quality on default risk (H1), we specify regression Eq. (6) as follows:

$$
\begin{aligned}
\operatorname{DEFAULT}_{i, t}= & \alpha_{o}+\beta_{1} C G Q_{i, t}+\beta_{2} R O A_{i, t}+\beta_{3} T L T A_{i, t}+\beta_{4} L I Q U I D_{i, t}+\beta_{5} \operatorname{Ln}(A G E)_{i, t} \\
& +\beta_{6} \operatorname{Ln}(T A)_{i, t}+\beta_{7} M T B_{i, t}+Y R_{t}+\varepsilon_{i, t}
\end{aligned}
$$

Where subscript $i$ denotes the individual firm $(i=1,2, \ldots, 1086), t$ equals the time period $(\mathrm{t}=$ $2001,2002, \ldots, 2013), L n$ is the natural logarithm, $\beta$ is parameter to be estimated, and $\varepsilon_{i, t}$ is the composite error including either industry dummies $\left(I N D_{i}\right)+$ idiosyncratic error $\left(V_{i, t}\right)$ or firm dummies $\left(\right.$ Firm $\left._{i}\right)+$ idiosyncratic error $\left(V_{i, t}\right)$ to control for the industry and firm fixed effects, respectively. DEFAULT = default risk proxy measures (either DD or CDS); CGQ = corporate governance quality proxy measures ( $C G$ index, board, audit, remuneration and nomination). The definition and details of the variables are as outlined in sections 4.2, 4.3, and 4.6 and are summarized in Table 1.

To test the corporate governance quality, growth opportunities and default risk hypothesis (H2), we formulate regression Eq. (7) as follows:

$$
\begin{aligned}
\operatorname{DEFAULT}_{i, t}= & \alpha_{o}+\beta_{1} \text { CGQ }_{i, t}+\beta_{2} \text { MTB }_{i, t}+\beta_{3} \text { CGQ }_{i, t} * \operatorname{MTB}_{i, t}+\beta_{4} R O A_{i, t}+\beta_{5} T L T A_{i, t} \\
& +\beta_{6} \operatorname{LIQUID}_{i, t}+\beta_{7} \operatorname{Ln}(A G E)_{i, t}+\beta_{8} \operatorname{Ln}(T A)_{i, t}+Y R_{t}+\varepsilon_{i, t}
\end{aligned}
$$

where $M T B=$ market to book value of equity; $C G Q * M T B=$ an interaction term comprising $C G Q$ multiplied by $M T B$. The definition and details of the variables are as outlined in sections 4.2, 4.3, 4.4 and 4.6 and are summarized in Table 1. Eq. (2) measures the partial effect of CGQ on default risk when growth opportunities are zero. Since it is very rare for the firms to have zero growth opportunities $(M T B)$, the interpretation of the CGQ coefficient would be meaningless. Thus, we measure the partial effect of CGQ on default risk at increasing levels of growth opportunities and specify it in regression Eq. (8) as follows:

$$
\begin{aligned}
\operatorname{DEFAULT}_{i, t}= & \alpha_{o}+\beta_{1} \text { CGQ }_{i, t}+\beta_{2} \text { MTB }_{i, t}+\beta_{3} C G Q_{i, t} *\left(M T B_{i, t}-\mu_{1}\right)+\beta_{4} R O A_{i, t} \\
& +\beta_{5} \text { TLTA }_{i, t}+\beta_{6} L I Q U I D_{i, t}+\beta_{7} \operatorname{Ln}(A G E)_{i, t}+\beta_{8} \ln (T A)_{i, t}+Y R_{t}+\varepsilon_{i, t}
\end{aligned}
$$

where $\mu_{1}$ take values from $10 \%, 25 \%, 50 \%, 75 \%$ or $90 \%$ for MTB. The coefficient $\beta_{1}$ measures the partial effect of CGQ on default risk when $\mu_{1}$ takes the value from $10 \%$ to $90 \%$ for growth opportunities (see Wooldridge, 2006, pp. 204-206).

To test the corporate governance quality, stock liquidity and default risk hypothesis (H3), we specify regression Eq. (9) as follows: 


$$
\begin{aligned}
\operatorname{DEFAULT}_{i, t}= & \alpha_{o}+\beta_{1} \operatorname{CGQ}_{i, t}+\beta_{2} \operatorname{SLIQ}_{i, t}+\beta_{3} C G Q_{i, t} * S L I Q_{i, t}+\beta_{4} R_{0} A_{i, t}+\beta_{5} T L T A_{i, t} \\
& +\beta_{6} \operatorname{LIQUID}_{i, t}+\beta_{7} \operatorname{Ln}(A G E)_{i, t}+\beta_{8} \operatorname{Ln}(T A)_{i, t}+\beta_{9} \text { MTB }_{i, t}+Y R_{t}+\varepsilon_{i, t}
\end{aligned}
$$

where $S L I Q=$ stock liquidity dummy variables $(T W Q S, A M I H U D$ and $L M)$, coded 1 (greater stock liquidity) if the value is below sample median, otherwise zero (lower stock liquidity); and $C G Q * S L I Q=$ an interaction term comprising CGQ multiplied by SLIQ dummy variables. The definition and details of the variables are as outlined in sections 4.2, 4.3, 4.5, and 4.6 and are summarized in Table 1.

To test three hypotheses, first, we employ pooled ordinary least square (OLS) including industry fixed effect. Then we employ the firm fixed effect (FE) method to control for unobserved heterogeneity due to time-unvarying omitted variables that differ across firms but are constant over time. While estimating the effects of independent variables on dependent variables, FE method focuses on overtime changes in the variables. Since this method focuses on the time-series variation between CGQ and default risk, and a causal relation between them can be examined using their time-series covariation, FE provides an additional insight into the empirical linkage between CGQ and default risk. ${ }^{13}$ In both OLS and FE methods the standard errors are clustered by firm to control for heteroskedasticity and within-firm correlation in the residuals (Petersen, 2009).

One may raise concern about reverse causality between CGQ and default risk that is, not only better CGQ leads to a lower default risk, but also higher default risk may trigger changes in CGQ simultaneously (Schultz et al., 2015). In other words, the firms facing high default risk may reconfigure their governance structure as a remedy to fix the deteriorating performance. We use three alternative model specifications to address this potential endogeneity concern. The first alternative replaces the contemporaneous values of CGQ and other control variables with one- or two-year lagged values. While regressions based on lagged values of independent variables might not remove endogeneity due to reverse causality, it would help mitigate the resulting bias in estimation.

The second alternative specification uses a two-stage least squares (2SLS) approach to further address the reverse causality issue. This 2SLS requires an instrumental variable (IV) that is strongly correlated with CGQ but does not have a direct influence default risk. Following Jiraporn et al. (2011), Liu et al. (2014), Yang and Zhao (2014), and Liu et al. (2015), we use the average CGQ of all the firms in firm i's industry (excluding firm i's score) as an IV. The intuition behind using industry-average CGQ as an IV is that a firm's governance arrangements (such as board and its subcommittees) might be highly related with the industry peers due to similar business mix and investment opportunities, but such industry average is unlikely to directly affect a firm's default risk (Yang and Zhao, 2014). Further to this, managers may influence governance choices of their own firm, but should have little or no influence on the governance choices of other firms. Given these arguments, industryaverage CGQ should be a valid instrument: it is unrelated to firm-level default risk but related

\footnotetext{
${ }^{13}$ We perform the Hausman test (Durbin, 1954; Hausman, 1978; Wu, 1973) to decide whether fixed effect (FE) or random effect (RE) is useful in model testing. The Hausman test suggests the use of FE.
} 
to firm-level CGQ. To cope with any counterarguments for IV, ${ }^{14}$ we assess the relevance and validity of the IV using the F-test for the joint significance of the instrument. A general rule of thumb is that if the F-statistics is more than 10 the IV is not weak (Staiger and Stock, 1997). As another point of check, we also test for the relevance of the IV using the CraggDonald (C-D) Wald test. IV is not classified as weak if the C-D statistic exceeds the StockYogo critical value at 5\% level (Stock and Yogo, 2005).

The third alternative specification includes a lagged default risk into main regression and estimates the augmented regression using the Arellano and Bover (1995) and Blundell and Bond (1998) dynamic two-step system GMM. In the dynamic system GMM, first-differenced variables are used as internal instruments for the equations in levels and the estimates are robust to endogeneity bias, if any (Pathan, 2009). ${ }^{15}$ Compared to the 2SLS method, dynamic GMM has at least two benefits. First, it handles the endogeneity bias with internally generated instruments rather than external instruments or natural experiments that may not be readily available. Second, it explicitly models the dynamic nature of the governance-default nexus by including prior year default risk as one of the regressors. The consistency of GMM estimation depends on two important conditions. The first condition is the serial independence of the residuals. The residuals in the first difference should be serially correlated (AR1) by way of construction but the residuals in the second difference should not be serially correlated (AR2). The second condition is the validity of instruments, which is tested through the Hansen J-statistics of over-identifying restrictions. The Hansen J-statistics of over-identifying restrictions tests the null hypothesis of instrument validity. We test the validity of these assumptions in the empirical results.

\subsection{Descriptive statistics}

\section{[Insert Table 2 here]}

Table 2 reports the descriptive statistics such as mean and standard deviation for the variables for whole sample and for the three sub-samples: pre reform (2001 to 2003), Post reform and pre GFC (2004 to 2007), post GFC (2010 to 2013). The default risk variables show that the mean $D D(C D S)$ is 3.52 (1.91) with a standard deviation of 2.50 (1.62). Overall, the default risk in the sample firms is low, implying that the firms are generally in good financial health. With regard to the CGQ variables, the average of the CG index is 8.53 (out of 17), suggesting that, on average, the CG structure of the sample firms is generally good and meets most of the best practice standards. The descriptive statistics of the firm characteristics indicate that the sample firms have average total assets of AUD \$436 million. On average, the sample firms carry $38 \%$ debt (TLTA) in their capital structure and have a return on assets (ROA) of $-15 \%$. Liquidity (LIQUID) and growth opportunities (MTB)

\footnotetext{
${ }^{14}$ Industry level default risk may influence particular firms and will in turn influence their CGQ and the industry's CGQ by aggregation.

${ }^{15}$ See Roodman (2009) for the detailed estimation procedure of dynamic panel data using 'xtabond2'.
} 
average 5.39 and 2.51 respectively. On average, the sample firms are 14.68 years old. ${ }^{16}$ In terms of sub-periods, we do observe the improvement in governance and reduction in default risk in the period after the reform compared to the pre reform period. However, the firm characteristics do not change substantially.

\section{[Insert Table 3 here]}

Table 3 provides year-wise and sector-wise descriptive statistics of the overall index (17 provisions) and sub-indices (i.e., board quality [3 provisions], audit quality [6 provisions], nomination quality [4 provisions], and remuneration quality [4 provisions]. Over the sample period, the governance quality of Australian firms has improved. For instance, overall index has increased from 6.26 in year 2001 to 10.31 in year 2013. Among the subindices, nomination quality in 2013 is the lowest (1.63 out of 4.00), followed by remuneration quality (2.38 out of 4.00), audit quality (4.03 out of 6.00) and board quality (2.27 out of 3.00). With regard to the sectors, consumer staples (material) outperformed (underperformed) in the overall index and sub-indices quality. Overall, from these descriptive statistics, we infer that the high (low) governance quality of any particular sector is supported by the high (low) scores in all sub-indices.

\section{Does CGQ affect default risk (H1)?}

\subsection{Main results}

We first examine if CGQ has a significant impact on default risk (H1). Table 4 presents the results of Eq. (6), where CGQ is measured by the self-constructed $C G$ index and default risk is measured by $D D$ and $C D S$. The results for $D D$ and $C D S$ as dependent variables are reported in columns 1-2 and 3-4, respectively. With regards to alternative methods, the results based on the pooled OLS method are presented in columns 1 and 3; and the FE method in columns 2 and 4. Industry and year fixed effects are controlled in the OLS method; firm and year fixed effects are controlled in FE method.

\section{[Insert Table 4 here]}

As hypothesized, the overall results indicate that CGQ has a negative and statistically significant relationship with default risk, suggesting that better-governed firms experience a lower level of default risk. For instance, with the OLS method, a 1 point rise in $C G$ index increases $D D$ and decreases $C D S$ by 0.021 points. With the FE method, a 1 point rise in $C G$ index increases $D D$ by 0.036 points and decreases $C D S$ by 0.021 points. ${ }^{17}$ The economic

\footnotetext{
${ }^{16}$ The correlation analysis indicates that CG index and governance categories have a strong positive (negative) correlation with $D D(C D S)$, suggesting better governed firms have a lower level of default risk. For brevity, we do not report these results.

${ }^{17}$ OLS regression captures the cross-sectional (across firms) and time-series (within) variation. However, fixed effect regression captures only the time series variation. Furthermore, if OLS results are significant and FE results are insignificant than it means our results are biased due to omitted variable bias. However, we notice that both OLS and FE method provide significant results. This finding suggests that omitted variable bias is less likely to an issue in our estimation.
} 
significance of this result is also important. For instance, an increase in the $C G$ index by one (sample) standard deviation would increase (decrease) $D D(C D S)$ by approximately $4.69 \%$ $(5.10 \%) .{ }^{18}$ Therefore, the results provide support for $\mathrm{H} 1$, indicating that better governed firms are likely to face a lower level of default risk. On the one hand, the composite CGQ based findings are consistent with the literature that argues better governance mechanisms reduce the agency problem, leading to reduction in the level of default risk (Chiang et al., 2015; Switzer and Wang, 2013). On the other hand, these findings provide guidelines for investors to use composite CGQ as a benchmark in the selection of stocks that are less likely to face default risk. ${ }^{19,20}$

With the FE method, the coefficients on the firm characteristics variables also offer an important insight. For instance, as expected, the positive (negative) and statistically significant coefficient on ROA indicates that, as a firm becomes more profitable, the $D D$ $(C D S)$ increases (decreases) and the default risk decreases. In line with the prediction, the coefficient on TLTA is negative (positive) and statistically significant at $1 \%$ level with $D D$ $(C D S)$, which indicates that the firm's leverage increases the default risk. The coefficient on LIQUID is positive (negative) with $D D(C D S)$ at the $1 \%$ significance level, which shows that firms with higher liquidity experience lower default risk. Similarly, the positive (negative) coefficient on $\operatorname{Ln}(A G E)$ for $D D(C D S)$ indicates that default risk diminishes as the firm survives longer (i.e. is listed for a longer period). Consistent with greater diversification benefits, the positive (negative) coefficient on $\operatorname{Ln}(T A)$ significant at the $1 \%$ level with $D D$ $(C D S)$ indicates that firm size lowers default risk. Likewise, the coefficient on $M T B$ is positive (negative) and statistically significant at the $1 \%$ level with $D D$ and $(C D S)$, implying that the default risk is less in firms with more growth opportunities.

The empirical evidence so far demonstrates a strong negative impact of CGQ on default risk. Now, we examine if governance categories (board, audit, nomination, and remuneration quality) have a significant impact on default risk. Specifically, we aim to understand which specific governance categories drive the results. Since some of the governance categories are correlated, we run separate regressions for each category to avoid multicollinearity problems. The results are reported in Table 5. As can be seen, all the governance categories are significantly related to the default risk. Overall, the evidence suggests that the relationship between CGQ and default risk is driven, not by a few, but by all governance categories. The impact of CGQ on default risk seems to be more general, not specific to any particular group

\footnotetext{
${ }^{18}$ We multiply the standard deviation of CG index i.e., 4.59 with the coefficient on $\mathrm{CG}$ index i.e., 0.036 in column 2 Table 4, and get 0.165 . Therefore, an increase in the CG index by one standard deviation improves $D D$ by 0.165 . As the mean $D D$ is 3.53 , an increase by 0.165 denotes a change by $4.68 \%$ of the average $D D$.

${ }^{19} \mathrm{We}$ also find that the inverse effect of governance on default risk holds in all the three sub-samples: prereform (years 2001 to 2003), post-reform and pre-GFC (years 2004 to 2007), and post-GFC (years 2010 to 2013) but the results are stronger for the period after the reform and before GFC compared to other two subsamples. Overall, we infer that the negative effect of governance on default risk is applicable to current market conditions i.e., post-GFC.

${ }^{20}$ We have done robustness check to only log transformations and winsorinsing at the more conventional $1 \%$ level. Specifically, we keep the key independent variable (CG index) at its original values as we observed no problem of outlier in the descriptive statistics. We also keep the dependent variables (DD and CDS) at their original values as extreme values on DD and CDS indicate worst performance (bankruptcy). To remove the potential outlier problems, we took the natural log of total assets (firm size) and firm age, and winsorized all other variables at $1 \%$ level. Our results (untabulated) remain robust.
} 
of governance provisions. However, it might be noted that there is a larger coefficient of board quality than those of the other categories. This is consistent with the notion that board quality (proportion of independent directors, absence of CEO duality and board meetings) is directly related to management control, preventing them from distorting information, reducing information asymmetry, and thus mitigating default risk.

\section{[Insert Table 5 here]}

On the one hand, this finding is in contrast to the prior Australian studies who find an insignificant relationship of board independence and CEO duality with default (Miglani et al., 2015; Schultz et al., 2015). On the other hand, we support the prior study of Daily and Dalton (1994), who find no individual effect of governance characteristics on bankruptcy; rather, an interaction effect of governance characteristics on bankruptcy; that is, the firms which are characterized with lower proportions of independent directors and that have CEO duality are more likely to collapse. Overall, these findings are in line with the argument that firms should focus on improving the governance quality as a whole if they wish to create value (Henry, 2008), and thus reduce the chances of default.

\subsection{Potential endogeneity}

As mentioned in section 4.7, the relationship between governance quality and default risk is spurious due to the endogeneity bias. We use three ways to address this potential endogeneity concern. First, we re-estimate Eq. (6) by using the current period's values of the $D D(C D S)$ (i.e., year t) and the prior period's CGQ and control variables (i.e., year t-1). Table 6 reports the results of lagged independent variables in columns 1-2 for $D D$ and columns 3-4 for $C D S$. The new estimates are virtually indistinguishable from the results reported in Table 4. The relation of CGQ with default risk is significantly negative at lag 1, lag 2 and lag 3 specifications. ${ }^{21}$ The evidence supports the interpretation that past CGQ influences current default risk, rather than past default risk influencing the current choice of CGQ. These results not only provide an additional support to the principal results but also suggest that CGQ has an ability to predict default risk, i.e., a high level in the CGQ 'current year' leads to a lower level of default risk 'next year'.

\section{[Insert Table 6 here]}

Second, we use an instrumental variable approach, 2SLS, to address the endogeneity bias and report the results in Panel A of Table 7. Column 1 contains the first-stage regression results. The coefficient on industry-average CGQ is positive and statistically significant at $1 \%$ level, implying that industry-average CGQ strongly explain firm-level CGQ. This shows the validity of IV because of its statistical power to explain firm-level CGQ. Moreover, the IV also passes the relevance test as the F-statistics is 432.89 that is well above 10 and is significant at $1 \%$ level. Columns 2 and 3 present the second-stage regression results, where either DD or CDS is the dependent variable (DEFAULT). We replace CGQ with the fitted CGQ from the first-stage regression. The coefficient on the fitted CGQ is positive (negative) for DD (CDS) and statistically significant, confirming the earlier findings, i.e., better CGQ

\footnotetext{
${ }^{21}$ For brevity we do not report the results of lag 2 and lag 3 . The results are similar when we take lag values of only the CG index.
} 
reduces the default risk of firms. The 2SLS results remain unaffected when we use alternative methods, i.e., information maximum likelihood and GMM. Thus, we conclude that the results are robust to the use of the 2 SLS approach.

As a robustness check, we use industry-location-average of corporate governance as an additional IV as suggested by Fisman and Svensson (2007) in their study on corruption. The use of industry-location average as an instrument not only overcomes the potential endogeneity of corporate governance, the bias from unobservable factors, but also mitigates measurement error in the data (Fisman and Svensson, 2007). A firm's corporate governance includes two elements:

$b_{i j t}=B_{i j t}+B_{j t}$

while $\mathrm{B}_{\mathrm{ijt}}$ is corporate governance of firm $i$ in industry $j$ at time $t$ by idiosyncratic reasons, $\mathrm{B}_{\mathrm{jt}}$ is the share of corporate governance by reasons relating to specific sector in a certain geographical location at time $t$. We conduct two-stage empirical estimation procedure. First, the location-industry-average corporate governance $\left(B_{j t}\right)$ along with other exogenous variables are used to estimate the fitted values for $\left(b_{i j t}\right)$. Then, we model default risk as a function of the fitted values from the first-stage regression and other exogenous variables. The unreported results provide additional support for the hypothesis that corporate governance has a significant negative effect on default risk.

\section{[Insert Table 7 here]}

Third, we use dynamic panel data estimation techniques to address the endogeneity bias. Panel B of Table 7 reports the results for $D D$ and $C D S$ in columns 4-6 and 7-9, respectively. With regards to alternative methods, the results based on the dynamic pooled OLS method are presented in columns 4 and 7; the dynamic FE method in columns 5 and 8; and the Arellano and Bover (1995) and Blundell and Bond (1998) dynamic two-step system generalized method of moments (GMM) in columns 6 and $9 .^{22}$ In the dynamic system GMM, first-differenced variables are used as instruments for the equations in levels and the estimates are robust to unobserved heterogeneity, reverse causality and dynamic endogeneity (if any). The diagnostics tests show that models 4-9 are well-fitted with statistically insignificant test statistics for the second-order autocorrelation in the second differences (AR2) and for the Hansen J-statistics of over-identifying restrictions. The interpretation of the coefficients on the $C G$ index remains qualitatively the same as in Table 4. Specifically, the statistically significant positive (negative) coefficients on the $C G$ index for $D D(C D S)$ across all the alternative specification of the dynamic panel data technique suggest that better CGQ is inversely related to default risk. Overall, the system GMM estimates support the notion that, even after controlling for unobserved heterogeneity, simultaneity and dynamic

\footnotetext{
${ }^{22}$ The dynamic pooled OLS and FE are reported to see if the coefficient of lagged DD (0.440) in the dynamic system GMM is between the coefficient of lagged DD in the dynamic pooled OLS (0.533) and FE (0.231).
} 
endogeneity, better governance is associated with default risk in a way that is consistent with the expectation. ${ }^{23}$

Several empirical studies also suggest natural experiment as a state-of-the-art solution to the endogeneity problem (see e.g., Black et al., 2015; Chen et al., 2015; Gippel et al., 2015). However, such a methodology requires a purely exogenous natural event. In the context of our study, one may suggest considering ASX CG reforms as a natural experiment; however, we are unable to use the reform as a natural experiment because the reform is not a mandate (i.e., quota law); rather, it is non-mandate (i.e., 'comply or explain'). Therefore, the change in firm-level corporate governance is still at the discretion of the firm and thus the impact of the reform is not credibly exogenous. In addition, the use of law changes and reforms as a natural experiment has recently been challenged by Karpoff and Wittry (2015).

Overall, we acknowledge that it is often difficult, if not impossible, to eliminate endogeneity completely. However, the various tests, based on lagged independent variables, 2SLS analysis and dynamic system GMM, should provide a certain degree of comfort that even when endogeneity due to reverse-causality is considered, the main findings regarding CGQ to default risk do not change. These findings contrast with the findings of Schultz et al. (2015), and provide empirical support to the development of comprehensive code of corporate governance practices in Australia.

\section{Growth opportunities and the impact of CGQ on default risk (H2)}

In this section, we investigate the role of growth opportunities in the relationship between CGQ and default risk (H2). To test this hypothesis, we first do the bivariate analysis by means of correlation metrics. We classify the sample firms into 5 quantiles, where quantile 1 consists of the low growth firms and quantile 5 consists of the high growth firms. The results reported in Table 8a reveal that when we move from low growth firms to high growth firms, the positive (negative) correlation between CG index and DD (CDS) has strengthened, meaning that CGQ significantly reduces default risk for the firms with more growth opportunities.

\section{[Insert Table 8a here]}

Second, we do the multivariate regression analysis. As specified in Eq. (7), Table 8b in Panel A presents the interaction effect of governance quality and growth opportunities on default risk in columns 1-2 and 3-4 for $D D$ and $C D S$, respectively. With regard to alternative methods, the results based on the pooled OLS method are presented in columns 1 and 2; and the FE method in columns 2 and 4.

\section{[Insert Table 8b here]}

Overall, the coefficient on the interaction term $(C G$ index*MTB) is statistically significant. More specifically, the coefficient on the interaction term is positive (negative) for

\footnotetext{
${ }^{23}$ We also use an external IV (industry-average CGQ) and find similar results (available upon request)
} 
$D D(C D S)$ and statistically significant at the $1 \%$ level across all alternative methods. These results suggest a moderation effect that the firms with better governance and more growth opportunities have a lower level of default risk. However, the coefficient on CGQ is negative (positive) for $D D(C D S)$ and statistically significant across most of the estimation methods, implying that the CGQ increases default risk for low growth firms. Given such findings, we further explore the partial effect of CGQ on default risk at an increasing level of growth opportunities $(10 \%, 25 \%, 50 \%, 75 \%$ or $90 \%)$ as specified in Eq. (8). The results reported in Panel B of Table 8 indicate that better CGQ does not seem to be associated with statistically significant lower default risk for low growth firms (MTB 10\%). However, better CGQ is found to sharply reduce the default risk for a firm with more growth opportunities (MTB 90\%). In fact, the slope (positive for $D D$ and negative for $C D S$ ) appears to be more than 5 times steeper. The significant positive (negative) coefficient on CGQ for $D D(C D S)$, confined to firms with more growth opportunities, indicates that CGQ reduces the default risk for firms with more growth opportunities but it does not do so for firms with fewer growth opportunities. The results (unreported) remain similar when we use an alternative proxy for growth opportunities (Tobin's Q) and with the individual governance categories (board, audit, nomination and remuneration). Therefore, we strongly accept $\mathrm{H} 2 .^{24}$

The economic meaning behind this finding is that effective CGQ reduces default risk by mitigating the information asymmetry problem between management and shareholders. Since high growth firms have plenty of simultaneous investment activities, compared to low growth firms, the high growth firms may have a more information-based asymmetry problem. These findings suggest that the role of CGQ is important in reducing default risk in a high growth firm which may suffer more from an information asymmetry problem. Overall, these results support the empirical literature that argues the relationship between CGQ and firm performance should be examined in the context of growth opportunities (see e.g., Hutchinson and Gul, 2004). Moreover, these findings complement the literature that argues the effect of CGQ on corporate outcomes is not homogenous across different types of firms (e.g., Coles et al., 2008). Specifically, this heterogeneity in the governance-default nexus provides empirical support to the 'comply or explain' governance regime in Australia and suggests that, while designing their corporate governance structure, firms should consider their growth conditions.

\section{Stock liquidity and the impact of CGQ on default risk (H3)}

In this section, we investigate the role of stock liquidity as the channel in the relationship between CGQ and default risk (H3). As specified in Eq. (9), Table 9 presents the interaction effect of corporate governance quality and stock liquidity on default risk in columns 1-3 for $D D$ and columns 4-6 for $C D S$.

\section{[Insert Table 9 here]}

\footnotetext{
${ }^{24}$ Similar to section 5.2, we check the endogeneity bias and find robust results (available upon request).
} 
Overall, the regression coefficient on the interaction term between CGQ and stock liquidity (i.e., $C G$ index*TWQS, $C G$ index*AMIHUD, and $C G$ index*LM in the regression models) is statistically significant. More specifically, the regression coefficient on $C G$ index*TWQS, CG index*AMIHUD, and $C G$ index*LM are positive (negative) for $D D(C D S)$ and statistically significant across all model specifications. Accordingly, H3 is supported by the results, suggesting that the firms with better corporate governance quality and greater stock liquidity have a significantly lower level of default risk. ${ }^{25}$ Furthermore, as expected, we also find that the coefficient on TWQS, $A M I H U D$, and $L M$ is positive (negative) for $D D$ $(C D S)$, suggesting that greater stock liquidity reduces default risk. These findings are in line with the study by Frino et al. (2007) and Brogaard et al. (2015), who show an increase in default risk for firms with poor stock liquidity.

Overall, this finding complements the two streams of literature: (1) corporate governance and stock liquidity (e.g., Chung et al., 2010), and (2) stock liquidity and default risk (e.g., Brogaard et al., 2015). Specifically, these results indicate the benefits of having a more independent governance structure in reducing default risk, through eliminating information asymmetry and improving stock liquidity. In other words, these findings suggest that firms with low stock liquidity should strive for high governance standards if they are to avoid future defaults.

To check the robustness, we use a split sample strategy to explore if corporate governance has a stronger effect on default risk for the firms that have low information asymmetry (i.e., firms with high stock liquidity). Using TWQS, Amihud, and LM, we split the sample into firms with high liquidity and firms with low liquidity. We classify a firm in a high liquidity (low liquidity) category if TWQS, Amihud, and LM are below (above) the sample median. Table 10 presents the fixed effect regression results. For low liquidity firms, CGQ does not seem to be associated with a statistically significant lower default risk. However, CGQ is found to sharply reduce default risk of firms with high stock liquidity. These findings confirm that corporate governance reduces default risk because it mitigates information asymmetry problems. Therefore, H3 of our study is strongly accepted.

\section{[Insert Table 10 here]}

\section{Internet Appendix: Additional analyses on does CGQ affect default risk}

\section{(H1)?}

In this section, we check the robustness of the main results (H1) to alternative default risk proxies, to alternative control variables, and to financial constraints. For the interest of brevity, the results are included in an internet appendix to this paper. First, we show that inverse relation of CGQ with default risk is robust to alternative proxy of default risk (i.e.,

\footnotetext{
${ }^{25}$ We repeat the analysis by using the continuous stock liquidity variables and find qualitatively similar results. Moreover, we also examine $\mathrm{H} 2$ and $\mathrm{H} 3$ together and find similar results (available upon request).
} 
probability of default and accounting-based Altman Z score) (see Internet Appendix IA1 for details). Second, we document that even after controlling additional and alternative variables (e.g., substantial shareholders and board size), the inverse relation between CGQ and default risk survives (see Internet Appendix IA2 for details). Finally, we show that the significant inverse impact of corporate governance on default risk exists only for the financial unconstrained firms (see Internet Appendix IA3 for details).

\section{Conclusion}

We contribute to the ongoing debate in literature: Does corporate governance quality affect default risk? It is timely and imperative to investigate the relationship between CGQ and default risk in the Australian context for three reasons. First, CGQ is the prime reason behind a series of defaults that occurred in Australia. Second, the Australian context-High agency costs, high ownership concentration, weak market for control and low litigation risk-is unique, so findings from other countries may not directly apply to Australia. Third, the scant Australian literature provides inconclusive evidence on the relationship between CGQ and default risk, when the endogeneity bias is considered.

Compared to Schultz et al. (2015), who use the sample of large Australian firms over the short period of 2001 to 2007, we provide additional evidence on the governance-default linkage by investigating such a relationship using firms from the different size groups (small, medium and large) over the long period from 2001 to 2013. Moreover, compared to the individual governance mechanisms used by Schultz et al. (2015), we employ a composite internal governance score based on the Horwath report. Furthermore, unlike Schultz et al. (2015), who employ only a market-based ( $D D$ and $P D$ ) proxy, we employ both market-based $(D D, C D S$ and $P D)$ and accounting-based (ALTMAN) proxies for default risk. Finally, we address endogeneity bias by using lagged independent variables, an instrumental variable approach, and dynamic panel data estimation techniques.

Our study, based on such methodological improvements, provides contrasting evidence, compared to that of Schultz et al. (2015). In particular, we show that the corporate governance quality of a firm is significantly relevant (negative) to its default risk in Australia. The findings are robust to an endogeneity bias, as well as to different estimation methods, to alternative proxies for default risk, and to alternative control variables. From a wider regulatory perspective, these index-based findings are supportive of the development of a comprehensive code of governance practice, as opposed to the adoption of individual governance practices. Additionally, these findings provide guidelines for investors to use composite governance as a benchmark in the selection of stocks that are less likely to face default.

We make two further major contributions to the existing literature. First we provide an insight into whether the effect of CGQ on default risk is homogeneous across degrees of growth opportunities. The results confirm that CGQ's significant reduction of default risk is 
mostly for firms with more growth opportunities. These results suggest that improvement in corporate governance is more effective in reducing default risk for the firms with high growth opportunities. Second, in a similar fashion, our study is the first to show that CGQ reduces default risk through the channel of information asymmetry, as captured by various dimensions of stock liquidity. Specifically, we find the interaction effect of CGQ and stock liquidity on default risk is stronger than the stand-alone partial effect of CGQ on default risk. These results imply that firms with poor stock liquidity should attempt to have high standards of corporate governance so that they can prevent future default conditions.

Overall, these findings suggest that CGQ is an important determinant of default risk, particularly for firms with high growth opportunities and greater stock liquidity. These findings have further implication for investors and firms. Investors require a risk premium for holding a stock of firms with low growth, poor stock liquidity and high default risk. Since we show that firms with better governance, high growth, and greater stock liquidity have a lower level of default risk, investors in these firms do not receive a risk premium; thus, the cost of equity for such firms is lower, which in turn is beneficial for improving firm value. Given these practical implications, investors and firms may wish to monitor the governance quality more closely so as to devise sound investment and corporate strategies, respectively.

The possible extensions to our study include but are not limited to: (1) the investigation of governance-default linkage using similar methodology in multi-countries accounting for institutional differences, (2) the in-depth investigation of the effect of GFC on the relationship between CGQ and default risk, (3) the exploration of governance mechanisms other than board structure such as boardroom gender diversity and managerial compensation that may affect the governance-default linkage, (4) the employment of the governance quality index in default prediction models as a key input to predict actual default events in Australia, and (5) the potential extension of this research to financial firms.

\section{References}

Adams, R. B., Ferreira, D., 2007. A theory of friendly boards. The journal of finance. 62, (1), 217-250.

Aitken, M., Frino, A., 1996. The determinants of market bid ask spreads on the australian stock exchange: Cross-sectional analysis. Accounting \& Finance. 36, (1), 51-63.

Ali, S., Liu, B., Su, J. J., 2016. What determines stock liquidity in Australia? Applied Economics. 48, (35), 3329-3344.

Amihud, Y., 2002. Illiquidity and stock returns: cross-section and time-series effects. Journal of Financial Markets. 5, (1), 31-56.

Arellano, M., Bover, O., 1995. Another look at the instrumental variable estimation of errorcomponents models. Journal of econometrics. 68, (1), 29-51.

Argenti, J., 1976. Corporate planning and corporate collapse. Long Range Planning. 9, (6), 12-17. 
Ashbaugh-Skaifea, H., Collinsb, D. W., LaFondc, R., 2006. The effects of corporate governance on firms' credit ratings. Journal of Accounting and Economics. 42, (1), 203-243.

Balcaen, S., Ooghe, H., 2006. 35 years of studies on business failure: An overview of the classic statistical methodologies and their related problems. The British Accounting Review. 38, (1), 63-93.

Beaver, W. H., 1966. Financial ratios as predictors of failure. Journal of Accounting Research. 4,, 71-111.

Beekes, W., Brown, P., Zhang, Q., 2015. Corporate governance and the informativeness of disclosures in Australia: a re-examination. Accounting \& Finance. 55, (4), 931-963.

Black, B. S., Kim, W., Jang, H., Park, K.-S., 2015. How corporate governance affect firm value? Evidence on a self-dealing channel from a natural experiment in Korea. Journal of Banking \& Finance. 51,, 131-150.

Black, F., 1971. Toward a fully automated stock exchange, part I. Financial Analysts Journal. 27, (4), 28-35.

Black, F., Scholes, M., 1973. The pricing of options and corporate liabilities. The journal of political economy. 81, (3), 637-654.

Blundell, R., Bond, S., 1998. Initial conditions and moment restrictions in dynamic panel data models. Journal of econometrics. 87, (1), 115-143.

Brogaard, J., Li, D., Xia, Y., 2015. The Effect of Stock Liquidity on Default Risk. Journal of Financial Economics, Forthcoming.

Chai, D., Faff, R., Gharghori, P., 2010. New evidence on the relation between stock liquidity and measures of trading activity. International Review of Financial Analysis. 19, (3), 181-192.

Chang, M., D'Anna, G., Watson, I., Wee, M., 2008. Does disclosure quality via investor relations affect information asymmetry? Australian Journal of Management. 33, (2), 375-390.

Chen, T., 2015. Institutions, board structure, and corporate performance: Evidence from Chinese firms. Journal of Corporate Finance. 32, 217-237.

Chen, T., Harford, J., Lin, C., 2015. Do analysts matter for governance? Evidence from natural experiments. Journal of financial Economics. 115, (2), 383-410.

Chiang, S. M., Chung, H., Huang, C. M., 2015. A note on board characteristics, ownership structure and default risk in Taiwan. Accounting \& Finance. 55, (1), 57-74.

Chung, K. H., Elder, J., Kim, J.-C., 2010. Corporate Governance and Liquidity. Journal of Financial and Quantitative Analysis. 45, (2), 265-291.

Clarke, F., Dean, G. W. 2007. Indecent disclosure: Gilding the corporate lily, Cambridge University Press.

Coles, J. L., Daniel, N. D., Naveen, L., 2008. Boards: Does one size fit all? Journal of financial economics. 87, (2), 329-356.

Collett, P., Hrasky, S., 2005. Voluntary disclosure of corporate governance practices by listed Australian companies. Corporate Governance: An International Review. 13, (2), 188196. 
Daily, C. M., Dalton, D. R., 1994. Bankruptcy and corporate governance: The impact of board composition and structure. Academy of Management Journal. 37, (6), 16031617.

Duan, J.-C., Van Laere, E., 2012. A public good approach to credit ratings-From concept to reality. Journal of Banking \& Finance. 36, (12), 3239-3247.

Durbin, J., 1954. Errors in variables. Review of the International Statistical. 22, (1/3), 23-32.

Elloumi, F., Gueyie, J.-P., 2001. Financial distress and corporate governance: an empirical analysis. Corporate Governance: The international journal of business in society. 1, (1), 15-23.

Fama, E. F., Jensen, M. C., 1983. Separation of ownership and control. The Journal of Law \& Economics. 26, (2), 301-325.

Fazzari, S. M., Hubbard, R. G., Petersen, B. C., Blinder, A. S., Poterba, J. M., 1988. Financing constraints and corporate investment. Brookings papers on economic activity. 1988, (1), 141-206.

Fisman, R., Svensson, J., 2007. Are corruption and taxation really harmful to growth? Firm level evidence. Journal of Development Economics. 83, (1), 63-75.

Frino, A., Jones, S., Wong, J. B., 2007. Market behaviour around bankruptcy announcements: Evidence from the Australian Stock Exchange. Accounting \& Finance. 47, (4), 713730.

Gaver, J. J., Gaver, K. M., 1993. Additional evidence on the association between the investment opportunity set and corporate financing, dividend, and compensation policies. Journal of Accounting and Economics. 16, (1), 125-160.

Gertler, M., Gilchrist, S., 1994. Monetary policy, business cycles, and the behavior of small manufacturing firms. The Quarterly Journal of Economics. 109, (2), 309-340.

Gharghori, P., Chan, H., Faff, R., 2006. Investigating the performance of alternative defaultrisk models: Option-based versus accounting-based approaches. Australian Journal of Management. 31, (2), 207-234.

Gippel, J., Smith, T., Zhu, Y., 2015. Endogeneity in Accounting and Finance Research: Natural Experiments as a State-of-the-Art Solution. Abacus. 51, (2), 143-168.

Glosten, L. R., Milgrom, P. R., 1985. Bid, ask and transaction prices in a specialist market with heterogeneously informed traders. Journal of financial economics. 14, (1), 71100.

Gompers, P., Ishii, J., Metrick, A., 2003. Corporate governance and equity prices. The Quarterly Journal of Economics. 118, (1), 107-156.

Goyenko, R. Y., Holden, C. W., Trzcinka, C. A., 2009. Do liquidity measures measure liquidity? Journal of financial economics. 92, (2), 153-181.

Graham, J. R., Lemmon, M. L., Schallheim, J. S., 1998. Debt, leases, taxes, and the endogeneity of corporate tax status. The journal of finance. 53, (1), 131-162.

Harrison, J. R., 1987. The strategic use of corporate board committees. California Management Review. 30, (1), 109-125. 
Haß, L. H., Vergauwe, S., Zhang, Q., 2014. Corporate governance and the information environment: Evidence from Chinese stock markets. International Review of Financial Analysis. 36, 106-119.

Hausman, J. A., 1978. Specification tests in econometrics. Econometrica: Journal of the Econometric Society. 46, (6), 1251-1271.

Henry, D., 2008. Corporate governance structure and the valuation of australian firms: Is there value in ticking the boxes? Journal of Business Finance \& Accounting. 35, (78), 912-942.

Henry, D., 2010. Agency costs, ownership structure and corporate governance compliance: A private contracting perspective. Pacific-Basin Finance Journal. 18, (1), 24-46.

Hermalin, B. E., Weisbach, M. S., 1988. The determinants of board composition. The RAND Journal of Economics. 19, (4), 589-606.

Hillegeist, S. A., Keating, E. K., Cram, D. P., Lundstedt, K. G., 2004. Assessing the probability of bankruptcy. Review of Accounting Studies. 9, (1), 5-34.

Huang, R. D., Stoll, H. R., 1996. Dealer versus auction markets: A paired comparison of execution costs on nasdaq and the nyse. Journal of financial Economics. 41, (3), 313357.

Hull, J. 2009. Options, futures and other derivatives, Pearson education.

Hutchinson, M., Gul, F. A., 2004. Investment opportunity set, corporate governance practices and firm performance. Journal of Corporate Finance. 10, (4), 595-614.

James-Overheu, C., Cotter, J., 2009. Corporate Governance and Sustainability Disclosures and the Assessment of Default Risk. Asian Journal of Finance \& Accounting. 1, (1).

Jensen, M. C., Meckling, W. H., 1976. Theory of the firm: Managerial behavior, agency costs and ownership structure. Journal of financial economics. 3, (4), 305-360.

Jiraporn, P., Kim, J. C., Kim, Y. S., 2011. Dividend payouts and corporate governance quality: An empirical investigation. Financial Review. 46, (2), 251-279.

Kang, H., Cheng, M., Gray, S. J., 2007. Corporate governance and board composition: Diversity and independence of Australian boards. Corporate Governance: An International Review. 15, (2), 194-207.

Karpoff, J. M., Wittry, M. D., 2015. Institutional and political economy considerations in natural experiments: The case of state antitakeover laws. Retrieved from http://papers.ssrn.com/sol3/papers.cfm?abstract_id=2493913

Klein, A., 2002. Audit committee, board of director characteristics, and earnings management. Journal of Accounting and Economics. 33, (3), 375-400.

Kyle, A. S., 1985. Continuous auctions and insider trading. Econometrica: Journal of the Econometric Society. 53, (6), 1315-1335.

La Porta, R., Lopez-de-Silanes, F., Shleifer, A., Vishny, R., 1998. Law and finance. Journal of Political Economy. 106, (6), 1113-1155.

Lasfer, M. A., 2002. Board structure and agency costs. Paper presented at the European Financial Management Association, London.

Leiper, N., 2002. Why Ansett Airlines failed and how to prevent it happening again. Current Issues in Tourism. 5, (2), 134-148. 
Linck, J. S., Netter, J. M., Yang, T., 2008. The determinants of board structure. Journal of financial Economics. 87, (2), 308-328.

Lipson, M. L., Mortal, S., 2009. Liquidity and capital structure. Journal of Financial Markets. 12, (4), 611-644.

Liu, W., 2006. A liquidity-augmented capital asset pricing model. Journal of financial Economics. 82, (3), 631-671.

Liu, Y., Mauer, D. C., 2011. Corporate cash holdings and CEO compensation incentives. Journal of financial Economics. 102, (1), 183-198.

Liu, Y., Miletkov, M. K., Wei, Z., Yang, T., 2015. Board independence and firm performance in China. Journal of Corporate Finance. 30, (1), 223-244.

Liu, Y., Wei, Z., Xie, F., 2014. Do women directors improve firm performance in china? Journal of Corporate Finance. 28, (1), 169-184.

Lyandres, E., Zhdanov, A., 2013. Investment opportunities and bankruptcy prediction. Journal of Financial Markets. 16, (3), 439-476.

Méndez, C. F., Pathan, S., García, R. A., 2015. Monitoring capabilities of busy and overlap directors: Evidence from Australia. Pacific-Basin Finance Journal. 35, 444-469.

Merton, R. C., 1974. On the pricing of corporate debt: The risk structure of interest rates*. The journal of finance. 29, (2), 449-470.

Miglani, S., Ahmed, K., Henry, D., 2010. Corporate governance and financial distress: Evidence from australia. Paper presented at the AFAANZ conference, Christchurch, New Zealand.

Miglani, S., Ahmed, K., Henry, D., 2015. Voluntary corporate governance structure and financial distress: Evidence from Australia. Journal of Contemporary Accounting \& Economics. 11, (1), 18-30.

Monem, R., 2011. The OneTel collapse: Lessons for corporate governance. Australian Accounting Review. 21, (4), 340-351.

Monem, R. M., 2013. Determinants of board structure: Evidence from Australia. Journal of Contemporary Accounting \& Economics. 9, (1), 33-49.

Myers, S. C., 1977. Determinants of corporate borrowing. Journal of financial Economics. 5, (2), 147-175.

Owen, N. (2003). Report of the HIH Royal Commission. Commonwealth of Australia, Canberra.

Pathan, S., 2009. Strong boards, ceo power and bank risk-taking. Journal of Banking \& Finance. 33, (7), 1340-1350.

Petersen, M. A., 2009. Estimating standard errors in finance panel data sets: Comparing approaches. Review of financial studies. 22, (1), 435-480.

Platt, H., Platt, M., 2012. Corporate board attributes and bankruptcy. Journal of Business Research. 65, (8), 1139-1143.

Prommin, P., Jumreornvong, S., Jiraporn, P., 2014. The effect of corporate governance on stock liquidity: The case of Thailand. International Review of Economics \& Finance. $32,132-142$. 
Roodman, D., 2009. A note on the theme of too many instruments. Oxford Bulletin of Economics and statistics. 71, (1), 135-158.

Rutherford, M. A., Buchholtz, A. K., 2007. Investigating the relationship between board characteristics and board information. Corporate Governance: An International Review. 15, (4), 576-584.

Schultz, E. L., Tan, D. T., Walsh, K. D., 2015. Corporate governance and the probability of default. Accounting \& Finance.

Smith, C. W., Watts, R. L., 1992. The investment opportunity set and corporate financing, dividend, and compensation policies. Journal of financial Economics. 32, (3), 263292.

Staiger, D., Stock, J., 1997. Instrumental variables regression with weak instruments. Econometrica. 65, (3), 557-586.

Stock, J. H., Yogo, M., 2005. Testing for weak instruments in linear IV regression. Identification and inference for econometric models: Essays in honor of Thomas Rothenberg (Cambridge University Press, Cambridge, UK).

Switzer, L. N., Wang, J., 2013. Default risk estimation, bank credit risk, and corporate governance. Financial Markets, Institutions \& Instruments. 22, (2), 91-112.

Tang, D. Y., Yan, H., 2010. Market conditions, default risk and credit spreads. Journal of Banking \& Finance. 34, (4), 743-753.

Upadhyay, A. D., Bhargava, R., Faircloth, S. D., 2014. Board structure and role of monitoring committees. Journal of Business Research. 67, (7), 1486-1492.

Weisbach, M. S., 1988. Outside directors and CEO turnover. Journal of financial Economics. 20, 431-460.

Windmeijer, F., 2005. A finite sample correction for the variance of linear efficient two-step gmm estimators. Journal of econometrics. 126, (1), 25-51.

Wooldridge, J. M. 2006. Introductory econometrics: A modern approach, 3 ed, Thomson SouthWestern, Ohio.

$\mathrm{Wu}, \mathrm{D} . \mathrm{M}$., 1973. Alternative tests of independence between stochastic regressors and disturbances. Econometrica: Journal of the Econometric Society. 41, (4), 733-750.

Yang, T., Zhao, S., 2014. CEO duality and firm performance: Evidence from an exogenous shock to the competitive environment. Journal of Banking \& Finance. 49,, 534-552.

Zahra, S. A., Pearce, J. A., 1989. Boards of directors and corporate financial performance: A review and integrative model. Journal of Management. 15, (2), 291-334. 
Table 1: Variables definitions

\begin{tabular}{ll}
\hline Notation & Variable name \\
\hline Panel A: Default risk (DEFAULT) \\
DD & Distance to default \\
CDS & Credit default swap spread \\
PD & Probability of default
\end{tabular}

Panel B: Corporate governance quality (CGQ)

CG index Corporate governance index

Board Board quality index

Audit Audit quality index

Nomination Nomination quality index

Remuneration Remuneration quality index

Panel C: Growth opportunities

MTB Growth opportunities

Panel D: Measures of stock liquidity (SLIQ)

TWQS Time-weighted quoted spread

Measures

Obtained from Risk Management Institute at NUS

Obtained from Risk Management Institute at NUS

Obtained from Risk Management Institute at NUS

CG index is a self-constructed index based on 17 objective criteria of the Horwath report, which ranges from 0 to 17 each year.

Board quality is a self-constructed board quality index based on respective criteria, which ranges from 0 to 3 .

Audit quality is a self-constructed audit quality index based on respective criteria, which ranges from 0 to 6 .

Nomination quality is a self-constructed governance category based on respective criteria, which ranges from 0 to 4 .

Remuneration quality is a self-constructed governance category based on respective criteria, which ranges from 0 to 4 .

Market value divided by book value of equity.

Daily ratio of time-weighted bid-ask spread divided by time-weighted mid-point spread averaged over a number of trading days in the financial year.

AMIHUD Amihud illiquidity estimate

Daily ratio of absolute stock return to trading volume in Australian dollars averaged over a number of trading days in the financial year.

LM Turnover-adjusted zero daily Turnover-adjusted zero daily volumes volumes

Panel E: Measures of control variables

$\begin{array}{ll}\text { ROA } & \begin{array}{l}\text { Profitability } \\ \text { TLTA }\end{array} \\ \text { LIQUID } & \begin{array}{l}\text { Liquidity } \\ \text { Ln(AGE) }\end{array} \\ \text { Firm age } \\ \text { YR } & \text { Firm size } \\ & \text { Year effect } \\ \text { IND } & \text { Industry effect } \\ & \end{array}$

Panel F: Instrumental variables (IV)

Industry- Industry-average average CGQ governance quality

corporate The average CGQ of all the firms in firm i's industry excluding firm i's CGQ 
Table 2: Descriptive statistics

\begin{tabular}{|c|c|c|c|c|c|c|c|c|c|c|c|c|c|c|c|}
\hline \multirow[b]{2}{*}{ Variables } & \multicolumn{6}{|c|}{$\begin{array}{l}\text { Whole sample } \\
2001 \text { to } 2013\end{array}$} & \multicolumn{3}{|c|}{$\begin{array}{c}\text { Pre reform } \\
2001 \text { to } 2003\end{array}$} & \multicolumn{3}{|c|}{$\begin{array}{c}\text { Post reform } \\
2004 \text { to } 2007\end{array}$} & \multicolumn{3}{|c|}{$\begin{array}{c}\text { Post GFC } \\
2010 \text { to } 2013\end{array}$} \\
\hline & Obs. & Mean & std. & Q1 & Median & Q3 & Obs. & Mean & Std. & Obs. & Mean & Std. & Obs. & Mean & Std. \\
\hline $\mathrm{DD}$ & 8851 & 3.52 & 2.50 & 1.71 & 3.07 & 4.81 & 1938 & 3.06 & 2.26 & 2898 & 4.09 & 2.64 & 2579 & 3.71 & 2.63 \\
\hline CDS & 8797 & 1.91 & 1.62 & 0.81 & 2.04 & 3.15 & 1921 & 2.19 & 1.57 & 2878 & 1.66 & 1.62 & 2566 & 1.67 & 1.64 \\
\hline CG index & 8851 & 8.53 & 4.58 & 5.00 & 9.00 & 12.00 & 1938 & 6.59 & 3.73 & 2898 & 8.44 & 4.52 & 2579 & 9.96 & 4.73 \\
\hline Board quality & 8851 & 2.10 & 0.68 & 2.00 & 2.00 & 3.00 & 1938 & 1.87 & 0.54 & 2898 & 2.08 & 0.69 & 2579 & 2.25 & 0.72 \\
\hline Audit quality & 8851 & 3.49 & 1.95 & 3.00 & 4.00 & 5.00 & 1938 & 2.95 & 1.86 & 2898 & 3.49 & 1.95 & 2579 & 3.88 & 1.93 \\
\hline Nomination quality & 8851 & 1.09 & 1.51 & 0.00 & 0.00 & 3.00 & 1938 & 0.45 & 1.06 & 2898 & 1.05 & 1.48 & 2579 & 1.57 & 1.64 \\
\hline $\begin{array}{l}\text { Remuneration } \\
\text { quality }\end{array}$ & 8851 & 1.85 & 1.54 & 0.00 & 2.00 & 3.00 & 1938 & 1.33 & 1.42 & 2898 & 1.82 & 1.52 & 2579 & 2.26 & 1.53 \\
\hline ROA (\%) & 8851 & -0.15 & 0.56 & -0.18 & 0.00 & 0.10 & 1938 & -0.17 & 0.55 & 2898 & -0.13 & 0.51 & 2579 & -0.13 & 0.56 \\
\hline TLTA (\%) & 8851 & 0.38 & 0.38 & 0.13 & 0.35 & 0.54 & 1938 & 0.40 & 0.33 & 2898 & 0.39 & 0.38 & 2579 & 0.35 & 0.38 \\
\hline LIQUID & 8851 & 5.39 & 10.58 & 1.13 & 1.83 & 4.46 & 1938 & 4.57 & 10.24 & 2898 & 5.33 & 10.63 & 2579 & 5.69 & 10.63 \\
\hline AGE (in years) & 8851 & 14.68 & 12.70 & 5.89 & 11.62 & 19.56 & 1938 & 12.67 & 12.14 & 2898 & 14.04 & 12.46 & 2579 & 17.04 & 13.10 \\
\hline $\operatorname{Ln}(\mathrm{AGE})$ & 8851 & 2.33 & 0.90 & 1.77 & 2.45 & 2.97 & 1938 & 2.13 & 0.95 & 2898 & 2.27 & 0.92 & 2579 & 2.56 & 0.77 \\
\hline $\operatorname{Ln}(\mathrm{TA})$ & 8851 & 18.04 & 2.17 & 16.55 & 17.89 & 19.41 & 1938 & 17.59 & 2.16 & 2898 & 17.89 & 2.16 & 2579 & 18.54 & 2.15 \\
\hline MTB & 8851 & 2.51 & 2.32 & 0.92 & 1.69 & 3.20 & 1938 & 2.24 & 2.19 & 2898 & 3.03 & 2.43 & 2579 & 2.17 & 2.18 \\
\hline
\end{tabular}

This table presents the distribution of variables by showing mean and standard deviation. See Table 1 for variable definitions. 
Table 3 Year-wise and sector-wise governance quality

\begin{tabular}{|c|c|c|c|c|c|}
\hline \multicolumn{6}{|c|}{ Panel A: Year wise averages of overall index and sub-indices } \\
\hline & CG Index & Board & Audit & Nomination & Remuneration \\
\hline 2001 & 6.26 & 1.80 & 2.85 & 0.33 & 1.29 \\
\hline 2002 & 6.33 & 1.85 & 2.85 & 0.36 & 1.27 \\
\hline 2003 & 7.19 & 1.95 & 3.14 & 0.66 & 1.44 \\
\hline 2004 & 8.04 & 2.04 & 3.37 & 0.93 & 1.71 \\
\hline 2005 & 8.37 & 2.09 & 3.49 & 1.01 & 1.79 \\
\hline 2006 & 8.61 & 2.10 & 3.53 & 1.12 & 1.86 \\
\hline 2007 & 8.70 & 2.11 & 3.56 & 1.14 & 1.90 \\
\hline 2008 & 8.61 & 2.14 & 3.52 & 1.13 & 1.83 \\
\hline 2009 & 9.08 & 2.19 & 3.62 & 1.30 & 1.97 \\
\hline 2010 & 9.48 & 2.20 & 3.72 & 1.44 & 2.11 \\
\hline 2011 & 9.84 & 2.25 & 3.84 & 1.56 & 2.19 \\
\hline 2012 & 10.31 & 2.28 & 3.95 & 1.69 & 2.40 \\
\hline 2013 & 10.31 & 2.27 & 4.03 & 1.63 & 2.38 \\
\hline \multicolumn{6}{|c|}{ Panel B: Industry-wise averages of overall index and sub-indices } \\
\hline & CG Index & Board & Audit & Nomination & Remuneration \\
\hline $\mathrm{CD}$ & 9.89 & 2.20 & 4.12 & 1.37 & 2.21 \\
\hline $\mathrm{CS}$ & 10.90 & 2.30 & 4.58 & 1.77 & 2.25 \\
\hline $\mathrm{E}$ & 7.33 & 2.06 & 2.92 & 0.84 & 1.50 \\
\hline $\mathrm{HC}$ & 9.26 & 2.25 & 3.83 & 1.15 & 2.03 \\
\hline I & 10.31 & 2.23 & 4.31 & 1.41 & 2.36 \\
\hline IT & 8.83 & 2.06 & 3.73 & 1.04 & 2.01 \\
\hline $\mathrm{M}$ & 6.88 & 1.94 & 2.73 & 0.78 & 1.43 \\
\hline $\mathrm{TS}$ & 9.79 & 2.14 & 3.89 & 1.59 & 2.16 \\
\hline $\mathrm{U}$ & 7.63 & 1.92 & 3.24 & 0.84 & 1.63 \\
\hline
\end{tabular}




\section{ACCEPTED MANUSCRIPT}

Table 4: CGQ and default risk (H1): Main results

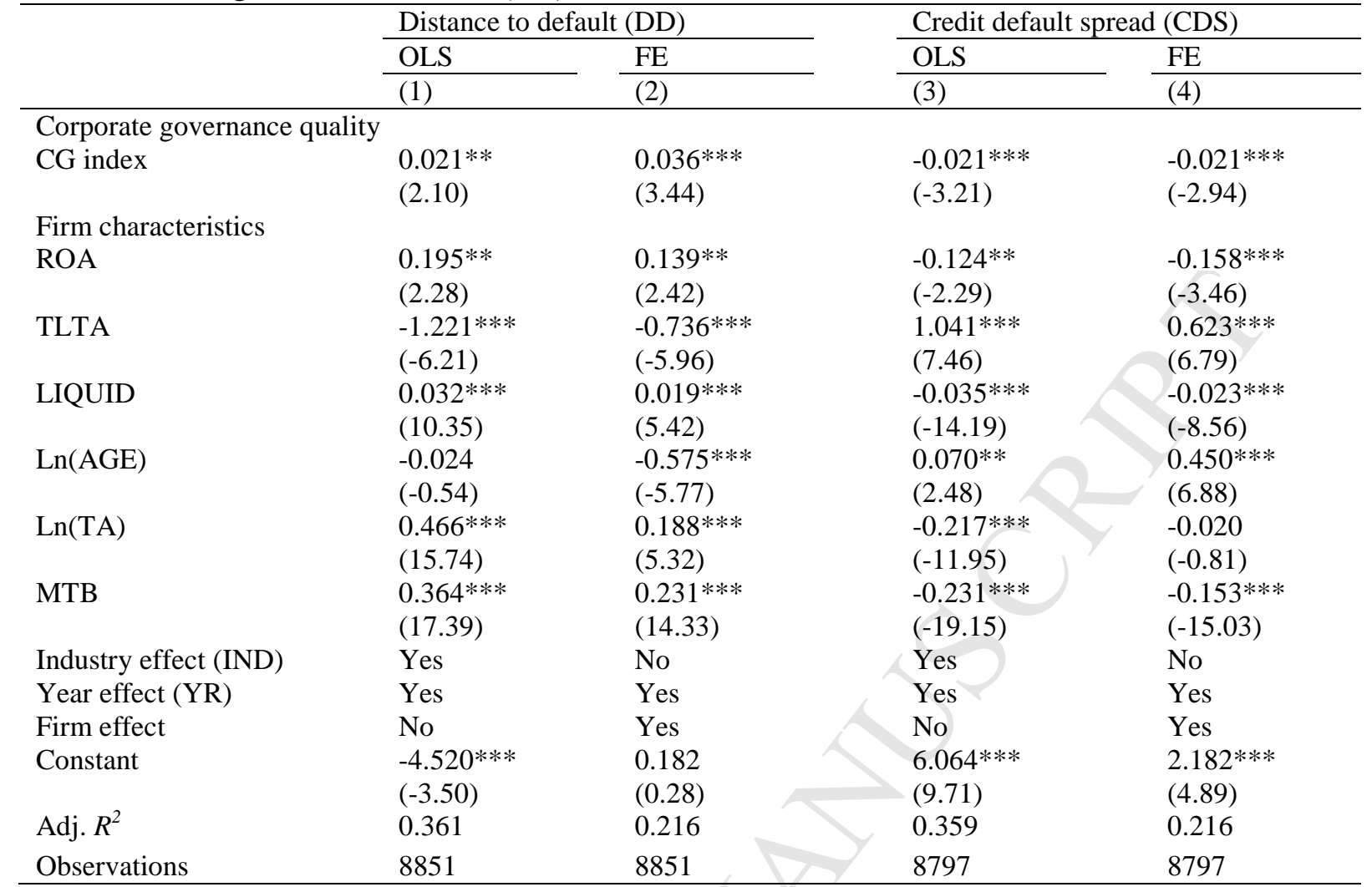

This table presents the regression results (using OLS and FE methods) between corporate governance quality and default risk. See Table 1 for variable definitions. Figures in parenthesis are the $t$-statistics. Standard errors are corrected based on one-way clustering by firm (e.g., Petersen, 2009). Superscripts ***, **, * indicate statistical significance at $1 \%, 5 \%$, and $10 \%$ respectively. 
Table 5: CGQ and default risk (H1): Individual governance categories

\begin{tabular}{|c|c|c|c|c|c|c|c|c|}
\hline & \multicolumn{4}{|c|}{ Distance to default (DD) } & \multicolumn{4}{|c|}{ Credit default spread (CDS) } \\
\hline & $\mathrm{FE}$ & $\mathrm{FE}$ & $\mathrm{FE}$ & $\mathrm{FE}$ & $\mathrm{FE}$ & $\mathrm{FE}$ & $\mathrm{FE}$ & $\mathrm{FE}$ \\
\hline & $(1)$ & $(2)$ & (3) & $(4)$ & $(5)$ & (6) & $(7)$ & $(8)$ \\
\hline \multicolumn{9}{|l|}{ Governance categories } \\
\hline Board & $\begin{array}{l}0.095^{* *} * \\
(2.03)\end{array}$ & & & & & & & \\
\hline Audit & & $\begin{array}{l}0.045^{* *} \\
(2.16)\end{array}$ & & & & $\begin{array}{l}-0.023 \\
(-1.49)\end{array}$ & & \\
\hline Nomination & & & $\begin{array}{l}0.068 * * * \\
(2.80)\end{array}$ & & & & $\begin{array}{l}-0.037 * * \\
(-2.23)\end{array}$ & \\
\hline Remuneration & & & & $\begin{array}{l}0.064 * * * \\
(2.70)\end{array}$ & & & & $\begin{array}{l}-0.044 * * * \\
(-2.71)\end{array}$ \\
\hline \multicolumn{9}{|l|}{ Firm characteristics } \\
\hline ROA & $\begin{array}{l}0.123 * * \\
(2.14)\end{array}$ & $\begin{array}{l}0.129 * * \\
(2.24)\end{array}$ & $\begin{array}{l}0.127 * * \\
(2.20)\end{array}$ & $\begin{array}{l}0.128 * * \\
(2.23)\end{array}$ & $\begin{array}{l}-0.148 * * * \\
(-3.23)\end{array}$ & $\begin{array}{l}-0.151 * * * \\
(-3.29)\end{array}$ & $\begin{array}{l}-0.150 \text { *** } \\
(-3.27)\end{array}$ & $\begin{array}{l}-0.152 \text { *** } \\
(-3.32)\end{array}$ \\
\hline LEV & $\begin{array}{l}-0.727 * * * \\
(-5.84)\end{array}$ & $\begin{array}{l}-0.734 * * * \\
(-5.94)\end{array}$ & $\begin{array}{l}-0.730 * * * \\
(-5.89)\end{array}$ & $\begin{array}{l}-0.735 * * * \\
(-5.93)\end{array}$ & $\begin{array}{l}0.619 * * * \\
(6.70)\end{array}$ & $\begin{array}{l}0.622 * * * \\
(6.77)\end{array}$ & $\begin{array}{l}0.620 * * * \\
(6.75)\end{array}$ & $\begin{array}{l}0.623 * * * \\
(6.79)\end{array}$ \\
\hline LIQUID & $\begin{array}{l}0.019 * * * \\
(5.38)\end{array}$ & $\begin{array}{l}0.019 * * * \\
(5.39)\end{array}$ & $\begin{array}{l}0.018 * * * \\
(5.37)\end{array}$ & $\begin{array}{l}0.019 * * * \\
(5.41)\end{array}$ & $\begin{array}{l}-0.023 * * * \\
(-8.52)\end{array}$ & $\begin{array}{l}-0.023 * * * \\
(-8.52)\end{array}$ & $\begin{array}{l}-0.023 * * * \\
(-8.52)\end{array}$ & $\begin{array}{l}-0.023 \text { *** } \\
(-8.55)\end{array}$ \\
\hline $\operatorname{Ln}(\mathrm{AGE})$ & $\begin{array}{l}-0.573 * * * \\
(-5.74)\end{array}$ & $\begin{array}{l}-0.571 * * * \\
(-5.72)\end{array}$ & $\begin{array}{l}-0.579 * * * \\
(-5.80)\end{array}$ & $\begin{array}{l}-0.571 * * * \\
(-5.73)\end{array}$ & $\begin{array}{l}0.449 * * * \\
(6.87)\end{array}$ & $\begin{array}{l}0.448 * * * \\
(6.84)\end{array}$ & $\begin{array}{l}0.452 \text { *** } \\
(6.90)\end{array}$ & $\begin{array}{l}0.447 * * * \\
(6.83)\end{array}$ \\
\hline $\operatorname{Ln}(\mathrm{TA})$ & $\begin{array}{l}0.224 * * * \\
(6.62)\end{array}$ & $\begin{array}{l}0.206^{* * * *} \\
(5.91)\end{array}$ & $\begin{array}{l}0.214 * * * \\
(6.29)\end{array}$ & $\begin{array}{l}0.206^{* * * *} \\
(5.91)\end{array}$ & $\begin{array}{l}-0.041 * \\
(-1.68)\end{array}$ & $\begin{array}{l}-0.033 \\
(-1.31)\end{array}$ & $\begin{array}{l}-0.036 \\
(-1.46)\end{array}$ & $\begin{array}{l}-0.028 \\
(-1.13)\end{array}$ \\
\hline MTB & $\begin{array}{l}0.232 * * * \\
(14.41)\end{array}$ & $\begin{array}{l}0.231 * * * \\
(14.34)\end{array}$ & $\begin{array}{l}0.232 * * * \\
(14.38)\end{array}$ & $\begin{array}{l}0.231 * * * \\
(14.35)\end{array}$ & $\begin{array}{l}-0.154 * * * \\
(-15.15)\end{array}$ & $\begin{array}{l}-0.154 * * * \\
(-15.05)\end{array}$ & $\begin{array}{l}-0.154 * * * \\
(-15.09)\end{array}$ & $\begin{array}{l}-0.154 * * * \\
(-15.04)\end{array}$ \\
\hline Industry effect (IND) & No & No & No & No & No & No & No & No \\
\hline Year effect (YR) & Yes & Yes & Yes & Yes & Yes & Yes & Yes & Yes \\
\hline Firm effect & Yes & Yes & Yes & Yes & Yes & Yes & Yes & Yes \\
\hline Constant & $\begin{array}{l}-0.396 \\
(-0.63)\end{array}$ & $\begin{array}{l}-0.047 \\
(-0.07)\end{array}$ & $\begin{array}{l}-0.066 \\
(-0.10)\end{array}$ & $\begin{array}{l}0.007 \\
(0.01)\end{array}$ & $\begin{array}{l}2.528 * * * \\
(5.67)\end{array}$ & $\begin{array}{l}2.341 * * * \\
(5.25)\end{array}$ & $\begin{array}{l}2.342 \text { *** } \\
(5.26)\end{array}$ & $\begin{array}{l}2.254 * * * \\
(5.03)\end{array}$ \\
\hline Adj. $R^{2}$ & 0.215 & 0.215 & 0.215 & 0.215 & 0.215 & 0.215 & 0.215 & 0.216 \\
\hline Observations & 8851 & 8851 & 8851 & 8851 & 8797 & 8797 & 8797 & 8797 \\
\hline
\end{tabular}

This table presents the regression results (using FE method) between corporate governance categories and default risk. See Table 1 for variable definitions. F 
Table 6: CGQ and default risk (H1): Lagged independent variables

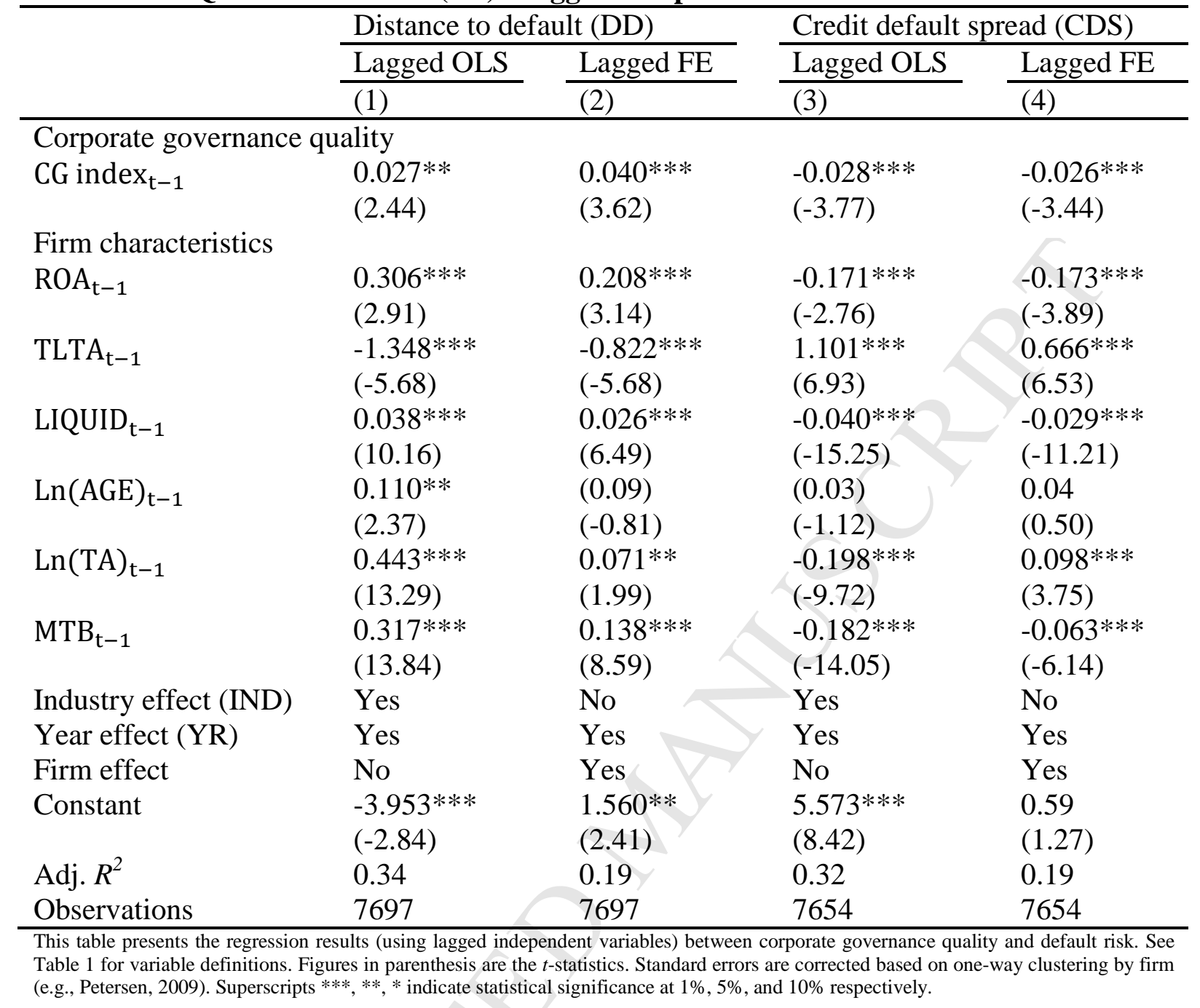


Table 7: CGQ and default risk (H1): Instrumental variable approach and dynamic panel data estimation

\begin{tabular}{|c|c|c|c|c|c|c|c|c|c|}
\hline & \multicolumn{3}{|c|}{ Panel A: Instrumental variable approach } & \multicolumn{6}{|c|}{ Panel B: Dynamic panel data estimation techniques } \\
\hline & \multirow{2}{*}{$\begin{array}{l}\text { First-stage } \\
\text { CGQ } \\
\end{array}$} & \multicolumn{2}{|c|}{ Second-stage } & \multirow{2}{*}{$\begin{array}{l}\text { Dynamic OLS } \\
\text { DD } \\
\end{array}$} & \multirow{2}{*}{$\begin{array}{l}\text { Dynamic FE } \\
\text { DD }\end{array}$} & \multirow{2}{*}{$\begin{array}{l}\text { Dynamic GMM } \\
\text { DD } \\
\end{array}$} & \multirow{2}{*}{$\begin{array}{l}\text { Dynamic OLS } \\
\text { CDS } \\
\end{array}$} & \multirow{2}{*}{$\begin{array}{l}\text { Dynamic FE } \\
\text { CDS } \\
\end{array}$} & \multirow{2}{*}{$\begin{array}{l}\text { Dynamic GMM } \\
\text { CDS } \\
\end{array}$} \\
\hline & & $\mathrm{DD}$ & CDS & & & & & & \\
\hline & $(1)$ & $(2)$ & (3) & (4) & $(5)$ & $(6)$ & $(7)$ & $(8)$ & $(9)$ \\
\hline \multicolumn{10}{|c|}{ Corporate governance quality } \\
\hline Industry-average CGQ & $\begin{array}{l}0.564 * * * \\
(21.18)\end{array}$ & & & & & & & & \\
\hline Fitted CGQ & & $\begin{array}{l}0.109 * * * \\
(3.77)\end{array}$ & $\begin{array}{l}-0.031^{*} \\
(-1.67)\end{array}$ & & & & & & \\
\hline L.DEFAULT & & & & $\begin{array}{l}0.533 * * * \\
(35.08)\end{array}$ & $\begin{array}{l}0.231 * * * \\
(13.62)\end{array}$ & $\begin{array}{l}0.440 * * * \\
(5.06)\end{array}$ & $\begin{array}{l}0.564 * * * \\
(57.29)\end{array}$ & $\begin{array}{l}0.305 * * * \\
(23.94)\end{array}$ & $\begin{array}{l}0.376 * * * \\
(5.78)\end{array}$ \\
\hline CG index & & & & $\begin{array}{l}0.019 * * * \\
(3.36)\end{array}$ & $\begin{array}{l}0.030 * * * \\
(3.01)\end{array}$ & $\begin{array}{l}0.121 * * * \\
(3.95)\end{array}$ & $\begin{array}{l}-0.019 * * * \\
(-5.39)\end{array}$ & $\begin{array}{l}-0.020 * * * \\
(-3.06)\end{array}$ & $\begin{array}{l}-0.109 * * * \\
(-5.29)\end{array}$ \\
\hline \multicolumn{10}{|l|}{ Firm characteristics } \\
\hline ROA & $\begin{array}{l}-0.475^{* * *} \\
(-5.86)\end{array}$ & $\begin{array}{l}0.202 * * * \\
(4.18)\end{array}$ & $\begin{array}{l}-0.093 * * * \\
(-2.97)\end{array}$ & $\begin{array}{l}0.204 * * * \\
(4.32)\end{array}$ & $\begin{array}{l}0.10 \\
(1.64)\end{array}$ & $\begin{array}{l}2.624 * * * \\
(3.79)\end{array}$ & $\begin{array}{l}-0.153^{* * * *} \\
(-4.69)\end{array}$ & $\begin{array}{l}-0.143^{* * * *} \\
(-3.29)\end{array}$ & $\begin{array}{l}-2.316^{* * * *} \\
(-4.24)\end{array}$ \\
\hline TLTA & $\begin{array}{l}(0.238) \\
(2.13)\end{array}$ & $\begin{array}{l}-1.314 * * * \\
(-19.30)\end{array}$ & $\begin{array}{l}1.107 * * * \\
(24.75)\end{array}$ & $\begin{array}{l}-0.615 * * * \\
(-7.72)\end{array}$ & $\begin{array}{l}-0.590 * * * \\
(-5.16)\end{array}$ & $\begin{array}{l}(0.77) \\
(-1.64)\end{array}$ & $\begin{array}{l}0.482 * * * \\
(8.96)\end{array}$ & $\begin{array}{l}0.452 * * * \\
(5.44)\end{array}$ & $\begin{array}{l}0.16 \\
(0.52)\end{array}$ \\
\hline LIQUID & $\begin{array}{l}-0.026 \\
(-7.08)\end{array}$ & $\begin{array}{l}0.035 * * * \\
(14.35)\end{array}$ & $\begin{array}{l}-0.036^{* * *} \\
(-22.95)\end{array}$ & $\begin{array}{l}0.021 * * * \\
(8.52)\end{array}$ & $\begin{array}{l}0.018 * * * \\
(4.91)\end{array}$ & $\begin{array}{l}0.040 * * \\
(2.05)\end{array}$ & $\begin{array}{l}-0.022 * * * \\
(-13.01)\end{array}$ & $\begin{array}{l}-0.020 * * * \\
(-7.94)\end{array}$ & $\begin{array}{l}-0.064 * * * \\
(-6.15)\end{array}$ \\
\hline $\operatorname{Ln}(\mathrm{AGE})$ & $\begin{array}{l}-0.292 \\
(-7.11)\end{array}$ & $\begin{array}{l}0.01 \\
(0.37)\end{array}$ & $\begin{array}{l}0.062 * * * \\
(3.59)\end{array}$ & $\begin{array}{l}0.146 * * * \\
(5.46)\end{array}$ & $\begin{array}{l}0.01 \\
(0.08)\end{array}$ & $\begin{array}{l}0.185 * * * \\
(2.95)\end{array}$ & $\begin{array}{l}-0.088 * * * \\
(-5.38)\end{array}$ & $\begin{array}{l}(0.09) \\
(-1.18)\end{array}$ & $\begin{array}{l}-0.145 * * * \\
(-2.92)\end{array}$ \\
\hline $\operatorname{Ln}(\mathrm{TA})$ & $\begin{array}{l}1.201 \\
(57.25)\end{array}$ & $\begin{array}{l}0.360 * * * \\
(9.47)\end{array}$ & $\begin{array}{l}-0.207 * * * \\
(-8.52)\end{array}$ & $\begin{array}{l}0.207 * * * \\
(12.69)\end{array}$ & $\begin{array}{l}0.143 * * * \\
(4.12)\end{array}$ & $\begin{array}{l}-0.361 * * * \\
(-2.70)\end{array}$ & $\begin{array}{l}-0.081 * * * \\
(-8.73)\end{array}$ & $\begin{array}{l}0.01 \\
(0.29)\end{array}$ & $\begin{array}{l}0.453 * * * \\
(4.54)\end{array}$ \\
\hline MTB & $\begin{array}{l}0.070 \\
(2.92)\end{array}$ & $\begin{array}{l}0.367 * * * \\
(37.02)\end{array}$ & $\begin{array}{l}-0.239 * * * \\
(-37.27)\end{array}$ & $\begin{array}{l}0.218 * * * \\
(20.05)\end{array}$ & $\begin{array}{l}0.197 * * * \\
(13.43)\end{array}$ & $\begin{array}{l}0.02 \\
(0.29)\end{array}$ & $\begin{array}{l}-0.135 * * * \\
(-21.57)\end{array}$ & $\begin{array}{l}-0.128 * * * \\
(-13.46)\end{array}$ & $\begin{array}{l}0.03 \\
(0.75)\end{array}$ \\
\hline Year effect (YR) & Yes & Yes & Yes & Yes & Yes & Yes & Yes & Yes & Yes \\
\hline Constant & $\begin{array}{l}-19.536^{* * * *} \\
(-45.41)\end{array}$ & $\begin{array}{l}-4.237 * * * \\
(-10.65)\end{array}$ & $\begin{array}{l}5.896^{* * * *} \\
(23.02)\end{array}$ & $\begin{array}{l}-3.024 * * * \\
(-11.34)\end{array}$ & $\begin{array}{l}(0.69) \\
(-1.07)\end{array}$ & $\begin{array}{l}7.311 * * * \\
(3.01)\end{array}$ & $\begin{array}{l}2.870 * * * \\
(16.94)\end{array}$ & $\begin{array}{l}1.886^{* * *} \\
(4.52)\end{array}$ & $\begin{array}{l}-6.073^{* * * *} \\
(-3.23)\end{array}$ \\
\hline Model fits: & & & & & & & & & \\
\hline $\begin{array}{l}\text { F-test (instrument) } \\
\text { Partial } R^{2}\end{array}$ & $\begin{array}{l}448.71 * * * \\
0.09\end{array}$ & & & & & & & & \\
\hline Hansen $J$-statistics & & N/A & N/A & N/A & N/A & $\begin{array}{l}3.03 \\
{[0.219]}\end{array}$ & N/A & N/A & $\begin{array}{l}2.67 \\
{[0.263]}\end{array}$ \\
\hline Adj. $R^{2}$ & 0.46 & 0.31 & 0.32 & 0.55 & 0.25 & N/A & 0.58 & 0.28 & N/A \\
\hline Arellano-Bond AR(1) & N/A & N/A & N/A & N/A & N/A & $\begin{array}{l}-17.40^{* * *} \\
{[0.000]}\end{array}$ & N/A & N/A & $\begin{array}{l}-17.29 * * * \\
{[0.000]}\end{array}$ \\
\hline Arellano-Bond AR(2) & N/A & N/A & N/A & N/A & N/A & $\begin{array}{l}0.07 \\
{[0.946]}\end{array}$ & N/A & N/A & $\begin{array}{l}0.16 \\
{[0.877]}\end{array}$ \\
\hline Observations & 8851 & 8851 & 8797 & 7698 & 7698 & 7698 & 7637 & 7637 & 7637 \\
\hline
\end{tabular}


This table presents the regression results between corporate governance quality and default risk using 2SLS in Panel A and using dynamic panel data estimation methods Panel B. See Table 1 for variable definitions. We use robust standard errors, incorporating the Windmeijer (2005) small-sample correction. Instruments are collapsed to reduce IV proliferation and preserve sample depth. Finally, Arellano-Bond AR(1) and AR(2) are the test statistics for first-order and second-order serial correlation, respectively. Hansen J-statistics is the test of over-identifying restrictions. Figures in parenthesis are the t-statistics. Standard errors are corrected based on one-way clustering by firm (e.g., Petersen, 2009). Superscripts ***, **, * indicate statistical significance at $1 \%, 5 \%$, and $10 \%$ respectively. 
Table 8a: Univariate analysis between CGQ and default risk at varying degrees of growth (H2)

Growth quantiles Correlation between CGQ and DD Correlation between CGQ and CDS

$\begin{array}{lll}\text { Q1 (Lowest) } & 0.092 & -0.026 \\ \text { Q2 } & 0.207 & -0.126 \\ \text { Q3 } & 0.276 & -0.163 \\ \text { Q4 } & 0.292 & -0.219 \\ \text { Q5 (Highest) } & 0.325 & -0.277\end{array}$

Table 8b: Joint effect of CGQ and growth opportunities on default risk (H2)

\begin{tabular}{|c|c|c|c|c|}
\hline & \multicolumn{2}{|c|}{ Distance to default (DD) } & \multicolumn{2}{|c|}{ Credit default spread (CDS) } \\
\hline & OLS & FE & OLS & FE \\
\hline & $(1)$ & $(2)$ & (3) & $(4)$ \\
\hline \multicolumn{5}{|c|}{ Panel A: Partial effect when MTB=0 } \\
\hline \multicolumn{5}{|c|}{ Corporate governance quality } \\
\hline \multirow[t]{2}{*}{ CG index } & $-0.042 * * *$ & $-0.023 *$ & $0.017 * *$ & 0.010 \\
\hline & $(-3.35)$ & $(-1.93)$ & $(1.98)$ & $(1.46)$ \\
\hline \multirow[t]{2}{*}{ МТВ } & $0.164 * * *$ & $0.065 * * *$ & $-0.112 * * *$ & $-0.059 * * *$ \\
\hline & $(5.39)$ & $(2.64)$ & $(-6.08)$ & $(-3.70)$ \\
\hline \multirow{2}{*}{ CG index*MTB } & $0.026 * * *$ & $0.023 * * *$ & $-0.015 * * *$ & $-0.013 * * *$ \\
\hline & $(7.02)$ & $(7.09)$ & $(-7.52)$ & $(-6.97)$ \\
\hline \multicolumn{5}{|l|}{ Firm characteristics } \\
\hline \multirow[t]{2}{*}{ ROA } & 0.11 & 0.08 & $(0.08)$ & $-0.127 * * *$ \\
\hline & $(1.33)$ & $(1.53)$ & $(-1.39)$ & $(-2.83)$ \\
\hline \multirow[t]{2}{*}{ LEV } & $-1.290 * * *$ & $-0.784 * * *$ & $1.083 * * *$ & $0.650 * * *$ \\
\hline & $(-6.58)$ & $(-6.20)$ & $(7.76)$ & $(6.93)$ \\
\hline \multirow[t]{2}{*}{ LIQUID } & $0.031 * * *$ & $0.018 * * *$ & $-0.035 * * *$ & $-0.023 * * *$ \\
\hline & $(10.15)$ & $(5.36)$ & $(-14.16)$ & $(-8.54)$ \\
\hline \multirow[t]{2}{*}{$\operatorname{Ln}(\mathrm{AGE})$} & $(0.02)$ & $-0.577 * * *$ & $0.067 * *$ & $0.451 * * *$ \\
\hline & $(-0.44)$ & $(-5.89)$ & $(2.38)$ & $(6.94)$ \\
\hline \multirow[t]{2}{*}{$\operatorname{Ln}(\mathrm{TA})$} & $0.474 * * *$ & $0.193 * * *$ & $-0.222 * * *$ & $(0.02)$ \\
\hline & $(16.27)$ & $(5.47)$ & $(-12.38)$ & $(-0.90)$ \\
\hline Industry effect (IND) & Yes & No & Yes & No \\
\hline Year effect (YR) & Yes & Yes & Yes & Yes \\
\hline Firm effect & No & Yes & No & Yes \\
\hline \multirow[t]{2}{*}{ Constant } & $-4.088 * * *$ & 0.52 & $5.804 * * *$ & $1.986 * * *$ \\
\hline & $(-3.27)$ & $(0.81)$ & $(9.68)$ & $(4.48)$ \\
\hline $\operatorname{Adj} . R^{2}$ & 0.37 & 0.23 & 0.37 & 0.23 \\
\hline Observations & 8851 & 8851 & 8797 & 8797 \\
\hline \multicolumn{5}{|c|}{ Panel B: Partial effect when MTB>0 } \\
\hline \multirow[t]{2}{*}{0.10} & $-0.029 * *$ & $(0.01)$ & 0.01 & 0.01 \\
\hline & $(-2.48)$ & $(-0.97)$ & $(1.10)$ & $(0.67)$ \\
\hline \multirow[t]{2}{*}{0.25} & $-0.019 *$ & $(0.00)$ & 0.00 & 0.00 \\
\hline & $(-1.70)$ & $(-0.16)$ & $(0.35)$ & $(0.03)$ \\
\hline \multirow[t]{2}{*}{0.50} & 0.00 & 0.02 & $(0.01)$ & $(0.01)$ \\
\hline & $(0.12)$ & $(1.61)$ & $(-1.35)$ & $(-1.38)$ \\
\hline \multirow[t]{2}{*}{0.75} & $0.040 * * *$ & $0.052 * * *$ & $-0.032 * * *$ & $-0.030 * * *$ \\
\hline & $(3.66)$ & $(4.73)$ & $(-4.77)$ & $(-4.14)$ \\
\hline \multirow[t]{2}{*}{0.90} & $0.114 * * *$ & $0.119 * * *$ & $-0.076 * * *$ & $-0.068 * * *$ \\
\hline & $(6.41)$ & $(7.04)$ & $(-7.83)$ & $(-6.91)$ \\
\hline
\end{tabular}

This table presents the regression results (using OLS and FE methods) on the interaction effect of corporate governance quality and growth opportunities on default risk in Panel A, and partial effect of corporate governance quality on default risk at different level of growth opportunities in Panel B. See Table 1 for variable definitions. Figures in parenthesis are the $t$-statistics. Standard errors are corrected based on one-way clustering by firm (e.g., Petersen, 2009). Superscripts $* * *, * * *$ indicate statistical significance at $1 \%, 5 \%$, and $10 \%$ respectively. 
Table 9: Joint effect of CGQ and stock liquidity on default risk (H3)

\begin{tabular}{|c|c|c|c|c|c|c|}
\hline & \multicolumn{3}{|c|}{ Distance to default (DD) } & \multicolumn{3}{|c|}{ Credit default spread (CDS) } \\
\hline & $\mathrm{FE}$ & $\mathrm{FE}$ & $\mathrm{FE}$ & $\mathrm{FE}$ & $\mathrm{FE}$ & $\mathrm{FE}$ \\
\hline & $(1)$ & $(2)$ & (3) & (4) & $(5)$ & $(6)$ \\
\hline \multicolumn{7}{|c|}{ Corporate governance quality } \\
\hline CG index & $\begin{array}{l}0.012 \\
(1.03)\end{array}$ & $\begin{array}{l}0.015 \\
(1.31)\end{array}$ & $\begin{array}{l}0.020^{*} \\
(1.70)\end{array}$ & $\begin{array}{l}-0.008 \\
(-1.16)\end{array}$ & $\begin{array}{l}-0.010 \\
(-1.54)\end{array}$ & $\begin{array}{l}-0.014 * * \\
(-2.16)\end{array}$ \\
\hline TWQS & $\begin{array}{l}0.586 * * * \\
(4.32)\end{array}$ & & & $\begin{array}{l}-0.385^{* * * *} \\
(-5.31)\end{array}$ & & \\
\hline CG index*TWQS & $\begin{array}{l}0.043 * * * \\
(3.38)\end{array}$ & & & $\begin{array}{l}-0.025 * * * \\
(-3.45)\end{array}$ & & \\
\hline Amihud & & $\begin{array}{l}0.385 * * * \\
(2.81)\end{array}$ & & & $\begin{array}{l}-0.255^{* * *} \\
(-3.66)\end{array}$ & \\
\hline CG index*Amihud & & $\begin{array}{l}0.041^{* * * *} \\
(3.06)\end{array}$ & & & $\begin{array}{l}-0.023 * * * \\
(-3.24)\end{array}$ & \\
\hline LM & & & $\begin{array}{l}0.302 * * * \\
(2.68)\end{array}$ & & & $\begin{array}{l}-0.176 * * * \\
(-2.63)\end{array}$ \\
\hline CG index*LM & & & $\begin{array}{l}0.030 \text { ** } \\
(2.46)\end{array}$ & & & $\begin{array}{l}-0.015 * * \\
(-2.07)\end{array}$ \\
\hline Firm characteristics & & & & & & \\
\hline ROA & $\begin{array}{l}0.200 * * * \\
(3.54)\end{array}$ & $\begin{array}{l}0.191 * * * \\
(3.38)\end{array}$ & $\begin{array}{l}0.193 * * * \\
(3.31)\end{array}$ & $\begin{array}{l}-0.193 * * * \\
(-5.72)\end{array}$ & $\begin{array}{l}-0.186 * * * \\
(-5.51)\end{array}$ & $\begin{array}{l}-0.183 * * * \\
(-5.35)\end{array}$ \\
\hline LEV & $\begin{array}{l}-0.774 * * * \\
(-6.70)\end{array}$ & $\begin{array}{l}-0.749 * * * \\
(-6.36)\end{array}$ & $\begin{array}{l}-0.736^{* * * *} \\
(-6.21)\end{array}$ & $\begin{array}{l}0.643 * * * \\
(13.89)\end{array}$ & $\begin{array}{l}0.625 * * * \\
(13.45)\end{array}$ & $\begin{array}{l}0.618^{* * * *} \\
(13.23)\end{array}$ \\
\hline LIQUID & $\begin{array}{l}0.018^{* * * *} \\
(5.23)\end{array}$ & $\begin{array}{l}0.018^{* * * *} \\
(5.14)\end{array}$ & $\begin{array}{l}0.018 * * * \\
(5.22)\end{array}$ & $\begin{array}{l}-0.023 * * * \\
(-16.12)\end{array}$ & $\begin{array}{l}-0.023 * * * \\
(-15.97)\end{array}$ & $\begin{array}{l}-0.023 * * * \\
(-16.08)\end{array}$ \\
\hline $\operatorname{Ln}(\mathrm{AGE})$ & $\begin{array}{l}-0.577 * * * \\
(-5.85)\end{array}$ & $\begin{array}{l}-0.587 * * * \\
(-5.89)\end{array}$ & $\begin{array}{l}-0.583 * * * \\
(-5.82)\end{array}$ & $\begin{array}{l}0.450 * * * \\
(10.13)\end{array}$ & $\begin{array}{l}0.455^{* * * *} \\
(10.19)\end{array}$ & $\begin{array}{l}0.453 * * * \\
(10.09)\end{array}$ \\
\hline $\operatorname{Ln}(\mathrm{TA})$ & $\begin{array}{l}0.005 \\
(0.13)\end{array}$ & $\begin{array}{l}0.052 \\
(1.42)\end{array}$ & $\begin{array}{l}0.083 * * \\
(2.22)\end{array}$ & $\begin{array}{l}0.095^{* * * *} \\
(4.88)\end{array}$ & $\begin{array}{l}0.063 * * * \\
(3.28)\end{array}$ & $\begin{array}{l}0.037^{*} \\
(1.88)\end{array}$ \\
\hline МTB & $\begin{array}{l}0.206 * * * \\
(13.16)\end{array}$ & $\begin{array}{l}0.214 * * * \\
(13.50)\end{array}$ & $\begin{array}{l}0.224 * * * \\
(14.00)\end{array}$ & $\begin{array}{l}-0.137 * * * \\
(-19.60)\end{array}$ & $\begin{array}{l}-0.142 * * * \\
(-20.25)\end{array}$ & $\begin{array}{l}-0.149 * * * \\
(-21.35)\end{array}$ \\
\hline Year effect (YR) & Yes & Yes & Yes & Yes & Yes & Yes \\
\hline Firm effect & Yes & Yes & Yes & Yes & Yes & Yes \\
\hline Constant & $\begin{array}{l}3.269 * * * \\
(5.03)\end{array}$ & $\begin{array}{l}2.532 * * * \\
(3.95)\end{array}$ & $\begin{array}{l}1.955 * * * \\
(2.92)\end{array}$ & $\begin{array}{l}0.260 \\
(0.77)\end{array}$ & $\begin{array}{l}0.766 * * \\
(2.28)\end{array}$ & $\begin{array}{l}1.240 * * * \\
(3.66)\end{array}$ \\
\hline Adj. $R^{2}$ & 0.244 & 0.235 & 0.228 & 0.135 & 0.126 & 0.116 \\
\hline Observations & 8851 & 8851 & 8851 & 8797 & 8797 & 8797 \\
\hline
\end{tabular}

This table presents the regression results (using FE method) on the interaction effect of corporate governance quality and stock liquidity on default risk. See Table 3.1 for variable definitions. Figures in parenthesis are the $t$-statistics. Standard errors are corrected based on one-way clustering by firm (e.g., Petersen, 2009). Superscripts ***,**,* indicate statistical significance at $1 \%, 5 \%$, and $10 \%$ respectively. 
Table 10: Joint effect of CGQ and stock liquidity on default risk: Split sample analysis

\begin{tabular}{|c|c|c|c|c|c|c|c|c|c|c|c|c|}
\hline & \multicolumn{6}{|c|}{ Distance to default } & \multicolumn{6}{|c|}{ Credit default spread (CDS) } \\
\hline & \multicolumn{2}{|l|}{ TWQS } & \multicolumn{2}{|l|}{ Amihud } & \multicolumn{2}{|l|}{ LM } & \multicolumn{2}{|l|}{ TWQS } & \multicolumn{2}{|l|}{ Amihud } & \multicolumn{2}{|l|}{ LM } \\
\hline & Low & High & Low & High & Low & High & Low & High & Low & High & Low & High \\
\hline & (1) & (2) & (3) & (4) & (5) & (6) & (7) & (8) & (9) & (10) & (11) & (12) \\
\hline \multicolumn{13}{|c|}{ Corporate governance quality } \\
\hline CG index & $\begin{array}{l}-0.001 \\
(-0.13)\end{array}$ & $\begin{array}{l}0.056 * * * \\
(3.48)\end{array}$ & $\begin{array}{l}0.001 \\
(0.05)\end{array}$ & $\begin{array}{l}0.055^{* * * *} \\
(3.25)\end{array}$ & $\begin{array}{l}0.007 \\
(0.53)\end{array}$ & $\begin{array}{l}0.052 * * * \\
(3.29)\end{array}$ & $\begin{array}{l}0.000 \\
(0.00)\end{array}$ & $\begin{array}{l}-0.027 * * * \\
(-2.82)\end{array}$ & $\begin{array}{l}-0.003 \\
(-0.34)\end{array}$ & $\begin{array}{l}-0.024 * * \\
(-2.34)\end{array}$ & $\begin{array}{l}-0.003 \\
(-0.34)\end{array}$ & $\begin{array}{l}-0.025 * * * \\
(-2.60)\end{array}$ \\
\hline \multicolumn{13}{|c|}{ Firm characteristics } \\
\hline ROA & $\begin{array}{l}0.083^{*} \\
(1.75)\end{array}$ & $\begin{array}{l}0.630^{*} \\
(1.69)\end{array}$ & $\begin{array}{l}0.085^{*} \\
(1.81)\end{array}$ & $\begin{array}{l}0.424 \\
(1.38)\end{array}$ & $\begin{array}{l}0.108 * \\
(1.94)\end{array}$ & $\begin{array}{l}0.434 * * \\
(2.41)\end{array}$ & $\begin{array}{l}-0.148 * * * \\
(-3.31)\end{array}$ & $\begin{array}{l}-0.586^{* *} \\
(-2.42)\end{array}$ & $\begin{array}{l}-0.149 * * * \\
(-3.48)\end{array}$ & $\begin{array}{l}-0.380^{*} \\
(-1.96)\end{array}$ & $\begin{array}{l}-0.144 * * * \\
(-2.99)\end{array}$ & $\begin{array}{l}-0.397 * * * \\
(-3.60)\end{array}$ \\
\hline LEV & $\begin{array}{l}-0.507 * * * \\
(-5.86)\end{array}$ & $\begin{array}{l}-2.716 * * * \\
(-4.08)\end{array}$ & $\begin{array}{l}-0.448 * * * \\
(-5.02)\end{array}$ & $\begin{array}{l}-2.450 * * * \\
(-4.27)\end{array}$ & $\begin{array}{l}-0.509 * * * \\
(-5.07)\end{array}$ & $\begin{array}{l}-1.417 * * * \\
(-2.97)\end{array}$ & $\begin{array}{l}0.469 * * * \\
(6.57)\end{array}$ & $\begin{array}{l}1.742 * * * \\
(4.27)\end{array}$ & $\begin{array}{l}0.432 * * * \\
(5.73)\end{array}$ & $\begin{array}{l}1.604 * * * \\
(4.52)\end{array}$ & $\begin{array}{l}0.466 * * * \\
(5.75)\end{array}$ & $\begin{array}{l}1.001 * * * \\
(3.16)\end{array}$ \\
\hline LIQUID & $\begin{array}{l}0.017 * * * \\
(4.66)\end{array}$ & $\begin{array}{l}-0.003 \\
(-0.40)\end{array}$ & $\begin{array}{l}0.021 * * * \\
(6.30)\end{array}$ & $\begin{array}{l}-0.006 \\
(-0.85)\end{array}$ & $\begin{array}{l}0.017 * * * \\
(4.19)\end{array}$ & $\begin{array}{l}0.008 \\
(1.27)\end{array}$ & $\begin{array}{l}-0.023 * * * \\
(-8.58)\end{array}$ & $\begin{array}{l}-0.005 \\
(-0.95)\end{array}$ & $\begin{array}{l}-0.025 * * * \\
(-8.96)\end{array}$ & $\begin{array}{l}-0.004 \\
(-0.81)\end{array}$ & $\begin{array}{l}-0.023 * * * \\
(-8.02)\end{array}$ & $\begin{array}{l}-0.013 * * * \\
(-2.96)\end{array}$ \\
\hline $\operatorname{Ln}(\mathrm{AGE})$ & $\begin{array}{l}-0.279 * * \\
(-2.35)\end{array}$ & $\begin{array}{l}-0.681 * * * \\
(-4.39)\end{array}$ & $\begin{array}{l}-0.363 * * * \\
(-3.21)\end{array}$ & $\begin{array}{l}-0.731 \text { **** } \\
(-4.57)\end{array}$ & $\begin{array}{l}-0.295 * * \\
(-2.40)\end{array}$ & $\begin{array}{l}-0.778 * * * \\
(-4.80)\end{array}$ & $\begin{array}{l}0.392 * * * \\
(4.40)\end{array}$ & $\begin{array}{l}0.405 * * * \\
(4.38)\end{array}$ & $\begin{array}{l}0.386^{* * * *} \\
(4.34)\end{array}$ & $\begin{array}{l}0.454 * * * \\
(4.72)\end{array}$ & $\begin{array}{l}0.359 * * * \\
(3.86)\end{array}$ & $\begin{array}{l}0.493^{* * * *} \\
(5.17)\end{array}$ \\
\hline $\operatorname{Ln}(\mathrm{TA})$ & $\begin{array}{l}0.130 * * * \\
(3.49)\end{array}$ & $\begin{array}{l}0.056 \\
(0.57)\end{array}$ & $\begin{array}{l}0.180 * * * \\
(4.88)\end{array}$ & $\begin{array}{l}0.082 \\
(0.91)\end{array}$ & $\begin{array}{l}0.141 * * * \\
(3.28)\end{array}$ & $\begin{array}{l}0.070 \\
(0.86)\end{array}$ & $\begin{array}{l}0.037 \\
(1.24)\end{array}$ & $\begin{array}{l}0.029 \\
(0.47)\end{array}$ & $\begin{array}{l}0.006 \\
(0.18)\end{array}$ & $\begin{array}{l}-0.001 \\
(-0.02)\end{array}$ & $\begin{array}{l}0.011 \\
(0.34)\end{array}$ & $\begin{array}{l}0.023 \\
(0.41)\end{array}$ \\
\hline МТВ & $\begin{array}{l}0.119 * * * \\
(8.60)\end{array}$ & $\begin{array}{l}0.380 * * * \\
(12.12)\end{array}$ & $\begin{array}{l}0.133 * * * \\
(8.61)\end{array}$ & $\begin{array}{l}0.360 * * * \\
(12.18)\end{array}$ & $\begin{array}{l}0.148 * * * \\
(8.71)\end{array}$ & $\begin{array}{l}0.332 * * * \\
(12.30)\end{array}$ & $\begin{array}{l}-0.097 * * * \\
(-8.81)\end{array}$ & $\begin{array}{l}-0.231 * * * \\
(-13.04)\end{array}$ & $\begin{array}{l}-0.103 * * * \\
(-8.79)\end{array}$ & $\begin{array}{l}-0.220 * * * \\
(-12.96)\end{array}$ & $\begin{array}{l}-0.110 * * * \\
(-8.79)\end{array}$ & $\begin{array}{l}-0.210 * * * \\
(-12.49)\end{array}$ \\
\hline Year effect (YR) & Yes & Yes & Yes & Yes & Yes & Yes & Yes & Yes & Yes & Yes & Yes & Yes \\
\hline Firm effect & Yes & Yes & Yes & Yes & Yes & Yes & Yes & Yes & Yes & Yes & Yes & Yes \\
\hline Constant & $\begin{array}{l}0.487 \\
(0.76)\end{array}$ & $\begin{array}{l}3.644 * * \\
(2.09)\end{array}$ & $\begin{array}{l}-0.274 \\
(-0.44)\end{array}$ & $\begin{array}{l}3.128^{*} \\
(1.93)\end{array}$ & $\begin{array}{l}0.356 \\
(0.49)\end{array}$ & $\begin{array}{l}3.060 * * \\
(2.05)\end{array}$ & $\begin{array}{l}1.508 * * * \\
(2.89)\end{array}$ & $\begin{array}{l}0.713 \\
(0.66)\end{array}$ & $\begin{array}{l}2.081 * * * \\
(3.91)\end{array}$ & $\begin{array}{l}1.237 \\
(1.20)\end{array}$ & $\begin{array}{l}1.953 * * * \\
(3.44)\end{array}$ & $\begin{array}{l}1.045 \\
(1.07)\end{array}$ \\
\hline Adj. R2 & 0.172 & 0.260 & 0.203 & 0.251 & 0.179 & 0.256 & 0.175 & 0.282 & 0.179 & 0.274 & 0.173 & 0.274 \\
\hline Observations & 4556 & 4394 & 4555 & 4395 & 4560 & 4390 & 4505 & 4388 & 4511 & 4382 & 4507 & 4386 \\
\hline
\end{tabular}

This table presents the regression results (using FE method) of corporate governance quality and default risk for high vs low stock liquidity firms. The firms are classified into high liquid (low liquid) group if the Petersen, 2009). Superscripts ***,**,* indicate statistical significance at $1 \%, 5 \%$, and $10 \%$ respectively. 


\section{Appendix}

\section{Appendix A: General procedure to calculate distance to default (DD)}

The Merton (1974) model views the firm's equity value as a European call option on the firm's assets, with a strike price equal to the face value of the firm's liabilities. This is because of the shareholders' limited liability and their residual claim on the firm's assets. If the firm's value exceeds the level of liabilities (strike price) at the time of maturity, when the value of the equity is positive, shareholders exercise their option and the firm survives. If the firm's value falls below the level of liabilities (strike price) at the time of maturity, when the value of equity becomes zero, the model assumes shareholders do not exercise their option and the firm defaults. Thus, the larger the positive distance between firm value and firm liabilities, the lower is the probability of default risk.

Value of firm $\left(V_{A}\right)=$ value of equity $\left(V_{e}\right)+$ Value of debt $(X)$

Value of equity $\left(V_{e}\right)=$ Value of firm $\left(V_{A}\right)-$ Value of debt $(X)$

Value of firm $\left(V_{A}\right)>$ Value of debt $(X) \rightarrow$ Value of equity $\left(V_{e}\right)$ is positive (firm survives)

Value of firm $\left(V_{A}\right)<$ Value of debt $(X) \rightarrow$ Value of equity $\left(V_{e}\right)$ is zero (firm defaults)

The Merton (1974) model has two important assumptions for the calculation of DD. First, it assumes that the value of the firm follows the geometric Brownian motion that is expressed as follows:

$d V_{A}=\mu V_{A} d t+\sigma_{A} V_{A} d W$

where $V_{A}$ denotes the value of firm's assets, $\mu$ represents expected continuously compounded returns on the firm's assets, $\sigma_{A}$ indicates instantaneous volatility of the firm's assets, and $d W$ is a standard Wiener process.

Second, the model assumes that the firm has only two securities outstanding; namely, common stock and a zero coupon bond maturing at time $(T)$.

Based on these two assumptions, the equity of the firm can be viewed as a call option on the value of the firm's assets, with a strike price equal to face value of the debt maturing at time $T$. Therefore, the market value of equity as a function of the total value of the firm's assets can be expressed by using Black and Scholes' (1973) formula for call options:

$V_{e}=V_{A} N\left(d_{1}\right)-X e^{-r T} N\left(d_{2}\right)$

where $V_{e}$ is the market value of the firm's equity, $X$ is the face value of the debt, $r$ is the riskfree rate, $T$ is the time horizon for the maturity of debt, $N$ symbolizes the function of the cumulative standard normal distribution, and $d_{1}$ and $d_{2}$ are given by the following formulas:

$d_{1}=\frac{\ln \left(\frac{V_{A}}{X}\right)+\left(r+\frac{1}{2} \sigma_{A}^{2}\right) T}{\sigma_{A} \sqrt{T}}, \quad d_{2}=d_{1}-\sigma_{A} \sqrt{T}$

In Eq. (A.2), $V_{e}, X, r$, and $T$ are readily observable and known factors, whereas $V_{A}$ and $\sigma_{A}$ are difficult to observe and are unknown factors. This means there are two unknowns in one 
equation, so a unique solution to Eq. (A.2) is not available. Thus, another equation involving one of the two unknown factors is required.

As in the Merton (1974) model, it is assumed that the value of the firm's equity is a function of the value of its assets and time, so the second equation that relates the volatility of the firm's equity to the volatility of the firm's assets can be written as:

$\sigma_{e}=\left(\frac{V_{A}}{V_{e}}\right) \frac{\partial V_{e}}{\partial V_{A}} \sigma_{A}$

According to the Black-Scholes-Merton model, the term $\frac{\partial V_{e}}{\partial V_{A}}$ in Eq. (A.4) is equal to $N\left(d_{1}\right)$, and can be rewritten as follows:

$$
\sigma_{e}=\left(\frac{V_{A}}{V_{e}}\right) N\left(d_{1}\right) \sigma_{A}
$$

Now, Eq. (A.2) and (A.5) can be solved simultaneously for the values of $V_{A}$ and $\sigma_{A}$, and DD can be calculated by using the following equation:

$$
D D=\frac{\ln \left(\frac{V_{A}}{X}\right)+\left(\mu-\frac{1}{2} \sigma_{A}^{2}\right) T}{\sigma_{A} \sqrt{T}}
$$

The probability of default (PD) is calculated as follows:

$P D=N(-D D)$

In a nutshell, for the calculation of DD, the following steps are required:

1) Estimating the volatility of the firm's equity $\left(\sigma_{e}\right)$ through historical stock price data or option-implied volatility data. Historical stock price data to estimate the volatility of the firm's equity is easily available. Following the Hull (2009) methodology, equity volatility can be calculated as:

$R_{i}=\operatorname{Ln}\left(p r_{t}-p r_{t-1}\right)$

where $R_{i}$ is the daily stock returns, $L n$ is the natural logarithm, $p r_{t}$ is the stock price at the end of the day and $p r_{t-1}$ is the stock price at the end of the previous day: $i=1,2,3 \ldots \mathrm{n}$. Annualized volatility is then estimated as:

$\sigma_{e}=\frac{1}{\sqrt{\frac{1}{n}}} \sqrt{\frac{1}{n-1 \sum_{i=1}^{n} R_{i}^{2}}}-\frac{1}{n(n-1)}\left(\sum_{i=1}^{n} R_{i}\right)^{2}$

where $n$ denotes the number of observations in one year i.e., number of trading days.

2) Selecting the forecasting horizon $(T)$. Generally, the forecast horizon is one year $(T=1)$.

3) Measuring the face value of the debt $(X)$. Generally, current liabilities plus half of the non-current liabilities are used to proxy the face value of debt, as also advised by Moody's KMV.

4) Collecting the risk-free rate (r). 3-month bank accepted bill or T-bills can be used to proxy risk-free rate.

5) Measuring the market value of equity $\left(V_{e}\right)$. It is calculated as the number of outstanding shares multiplied by market price per share.

6) Solving Eq. (A.2) and (A.5) simultaneously for the values of $\left(V_{A}\right)$ and $\left(\sigma_{e}\right)$, and then calculate the DD using Eq. (A.6) and PD using Eq. (A.7). 


\section{Appendix B: Horwath corporate governance report 2008}

\section{Board of Directors}

1.1 The most desirable outcome will be for a company to have:

1.1.1 A board with the majority of independent directors;

1.1.2 An independent chairperson; and

1.1.3 Met at least six times annually

1.2 The least desirable outcome will be for a company to have:

1.2.1 A board with no independent directors

1.2.2 The CEO as chairperson; and

1.2.3 Met less than six times annually.

\section{Audit Committee}

2.1 The most desirable outcome will be for a company to have an audit committee:

2.1.1 With all the members, including the chair, independent;

2.1.2 With a chair, who is not also the chair of the main board;

2.1.3 With at least one member with professional or educational accounting qualifications;

2.1.4 With at least three members;

2.1.5 That does not comprise the full board; and

2.1.6 That meets at least four times annually.

2.2 The least desirable outcome will be for a company not to have an audit committee

\section{Remuneration Committee}

3.1 The most desirable outcome will be for a company to have a remuneration committee:

3.1.1 With all the members, including the chair, independent;

3.1.2 With at least three members; and

3.1.3 That does not comprise the full board.

3.2 The least desirable outcome will be for a company not to have a remuneration committee.

\section{Nomination Committee}

4.1 The most desirable outcome will be for a company to have a nomination committee:

4.1.1 With all the members, including the chair, independent;

4.1.2 With at least three members; and

4.1.3 That does not comprise the full board

4.2 The least desirable outcome will be for a company not to have a nomination committee.

\section{External Auditor Independence}

5.1 Weighting is placed on the proportion of non-audit fees (relative to audit fees) paid by a client to their auditor, and the policy relating to the provision of non-audit services.

\section{Code of Conduct and Other Policy Disclosures}

6.1 A weighting is included for the quality of disclosures relating to the existence and substance of a company's:

\subsubsection{Code of Conduct;}

6.1.2 Policy on risk management;

6.1.3 Policy on share trading; and

6.1.4 Clarity of corporate governance disclosures. 


\begin{tabular}{clcc} 
Appendix C: Simplified CGQ index & & \\
\hline Number & Governance categories & & \\
\hline 1 & Board of Directors & 1 & 0 \\
\hline 1.1 & A board with the majority of independent directors & 1 & 0 \\
1.2 & An independent chairperson; and & 1 & 0 \\
1.3 & Met at least six times annually & 1 & 0 \\
\hline 2 & Audit Committee & 1 & 0 \\
\hline 2.1 & Existence of audit committee & 1 & 0 \\
2.2 & With all the members, including the chair, independent; & 1 & 0 \\
2.3 & With a chair, who is not also the chair of the main board; & 1 & 0 \\
2.4 & With at least three members; & 1 & 0 \\
2.5 & That does not comprise the full board; and & & \\
2.6 & That meets at least four times annually. & 1 & 0 \\
\hline 3 & Remuneration Committee & 1 & 0 \\
\hline 3.1 & Existence of remuneration committee & 1 & 0 \\
3.2 & With all the members, including the chair, independent; & 1 & 0 \\
3.3 & With at least three members; and & & \\
\hline 3.4 & That does not comprise the full board. & 1 & 0 \\
\hline 4 & Nomination Committee & 1 & 0 \\
\hline 4.1 & Existence of nomination committee & 1 & 0 \\
4.2 & With all the members, including the chair, independent; & 0 \\
4.3 & With at least three members; and & 1 & \\
\hline 4.4 & That does not comprise the full board & & \\
\hline
\end{tabular}




\section{Internet Appendix}

\section{Internet Appendix IA1: Alternative default risk proxies}

In the main analysis, we employ two market-based proxies for default risk to test the hypothesis H1. However, in this section, we check the robustness of the main results by using alternative proxies for default risk. First, we employ an alternative market-based proxy for default risk that is probability of default $(P D)$, which is derived from the Merton distance to default (DD) scores. In particular, we employ one, two, three and five year's default probabilities. $P D$ ranges from ' 0 ' to ' 1 ' where $P D$ near to ' 0 ' represents healthy firm and $P D$ near to ' 1 ' represents defaulted firm. This suggests that the higher the $P D$, the higher is the default risk. Second, we use accounting-based proxy for default risk. Past research has mostly relied on financial ratios as a proxy for default risk because they consider financial ratios as important indicators of financial status which could signal conditions of default. Thus, as a sensitivity analysis of the main results, we employ a modified Altman Z score (Graham et al., 1998 ) as a proxy for default risk. We compute Altman as follows:

Altman $=1.2\left(X_{1}\right)+1.4\left(X_{2}\right)+3.3\left(X_{3}\right)+0.999\left(X_{4}\right)$

where Altman is the default risk; $X_{1}$ is the working capital divided by total assets; $X_{2}$ is the retained earnings divided by total assets; $X_{3}$ is the earnings before interest and tax divided by total assets; $X_{4}$ is the sales divided by total assets. Higher the Altman, lower is the degree of default risk.

Table IA.1: CGQ and default risk (H1): Alternative proxies for default risk

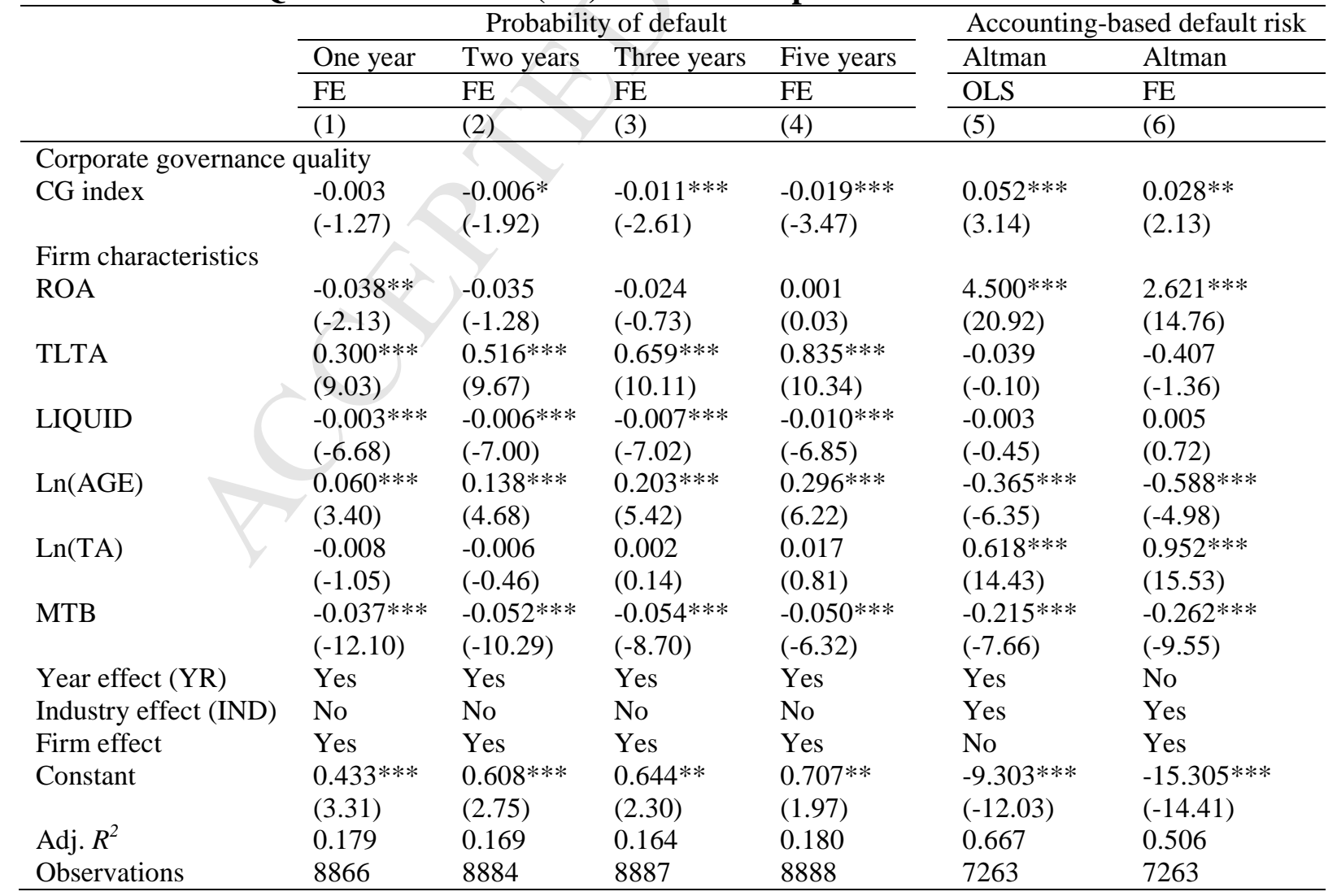


This table presents the regression results on the effect of corporate governance quality on alternative proxies for default risk. See Table 1 for variable definitions. Figures in parenthesis are the $t$-statistics. Standard errors are corrected based on one-way clustering by firm (e.g., Petersen, 2009). Superscripts $* * *, * *, *$ indicate statistical significance at $1 \%, 5 \%$, and $10 \%$ respectively.

We report the regression results for the main hypothesis (H1) based on alternative measure of default risk ( $P D$ and ALTMAN) in Table IA.1. Columns 1-4 is for PD and Columns 5-6 is for Altman in Panel B). The FE regression results confirm the presence of a strong negative effect of governance quality on $P D$ across various default probability specifications (two, three, and five years); implying that corporate governance reduces default risk. Moreover, regression results show a statistically significant and positive regression coefficient on corporate governance for Altman across all regression model specifications (OLS and FE). Hence, the results using accounting-based proxy for default risk provide an additional support for H1. Overall, these results suggest that the main results are robust to the change in the default risk measurement.

\section{Internet Appendix IA2: Alternative control variables}

In this section, we use alternative and additional control variables in the regression model to address any misspecification error or omitted available bias. First, we replace 'net income over total asset' with 'earnings before interest and taxes over total assets' as a measure of ROA. Second, we replace 'current assets over current liabilities' with 'cash over current liabilities' as a measure for LIQUID. Such specifications of ROA and LIQUID are more precise in measuring whether the firm has the ability to meet its debt obligations. Third, we include interest coverage ratio (ICR) which is measured as earnings before interest and taxes divided by interest paid. ICR seems a more appropriate ratio to default risk because it has interest in the denominator, rather than in the general categories of total assets and liabilities. Fourth, prior literature suggest that the ownership concentration and board size may affect a firm's default risk (Chiang et al., 2015). Hence, we include ownership concentration (Block) and board size (BSize) as an additional control variable. Block is measured as a percentage of outstanding shares held by substantial shareholders, and BSize is measured as a number of directors in the board (BSize). Finally, we include the average number of outside directorships held by the board (DIRECTORSHIPS) (Elloumi and Gueyie, 2001).

Table IA.2 reports the regression results for the main hypothesis (H1), based on the alternative measure of control variables. The results show a statistically significant and positive (negative) regression coefficient on corporate governance for $D D(C D S)$ across all regression model specifications (OLS, FE, and BE). Hence, the results using alternative control variables provide an additional support for $\mathrm{H} 1 .^{26}$

\footnotetext{
${ }^{26}$ Moreover, we check the robustness of the main results (H1) to alternative sample specifications such as excluding GFC observations (2008-2009), unbalanced data, and excluding largest 10 percent or the smallest 10 percent sample firms. We note that our main are unaffected by such sample specifications. Results are available upon request.
} 
Table IA.2: CGQ and default risk (H1): Alternative proxies for control variables

\begin{tabular}{|c|c|c|c|c|}
\hline & \multicolumn{2}{|c|}{ Distance to default (DD) } & \multicolumn{2}{|c|}{ Credit default spread (CDS) } \\
\hline & OLS & $\mathrm{FE}$ & OLS & $\mathrm{FE}$ \\
\hline & $(1)$ & $(2)$ & $(3)$ & $(4)$ \\
\hline \multicolumn{5}{|l|}{ Corporate governance quality } \\
\hline CG index & $\begin{array}{l}0.012 * \\
(1.81)\end{array}$ & $\begin{array}{l}0.038 * * * \\
(3.60)\end{array}$ & $\begin{array}{l}-0.008 * * \\
(-1.99)\end{array}$ & $\begin{array}{l}-0.021 * * * \\
(-2.96)\end{array}$ \\
\hline \multicolumn{5}{|l|}{ Firm characteristics } \\
\hline ROA & $\begin{array}{l}0.225 * * * \\
(4.37)\end{array}$ & $\begin{array}{l}0.141 * * \\
(2.34)\end{array}$ & $\begin{array}{l}-0.190 * * * \\
(-5.70)\end{array}$ & $\begin{array}{l}-0.163 \text { *** } \\
(-3.49)\end{array}$ \\
\hline LEV & $\begin{array}{l}-1.381 * * * \\
(-20.28)\end{array}$ & $\begin{array}{l}-0.768 * * * \\
(-5.88)\end{array}$ & $\begin{array}{l}1.015^{* * * *} \\
(22.71)\end{array}$ & $\begin{array}{l}0.571 * * * \\
(6.09)\end{array}$ \\
\hline $\operatorname{Ln}(\mathrm{AGE})$ & $\begin{array}{l}-0.047 * \\
(-1.87)\end{array}$ & $\begin{array}{l}-0.604 * * * \\
(-5.92)\end{array}$ & $\begin{array}{l}0.063 * * * \\
(3.92)\end{array}$ & $\begin{array}{l}0.442 * * * \\
(6.74)\end{array}$ \\
\hline $\operatorname{Ln}(\mathrm{TA})$ & $\begin{array}{l}0.466 * * * \\
(25.97)\end{array}$ & $\begin{array}{l}0.237 * * * \\
(6.33)\end{array}$ & $\begin{array}{l}-0.264 * * * \\
(-22.86)\end{array}$ & $\begin{array}{l}-0.093 * * * \\
(-3.59)\end{array}$ \\
\hline MTB & $\begin{array}{l}0.349 * * * \\
(34.93)\end{array}$ & $\begin{array}{l}0.223 * * * \\
(13.60)\end{array}$ & $\begin{array}{l}-0.192 * * * \\
(-30.01)\end{array}$ & $\begin{array}{l}-0.136 * * * \\
(-13.26)\end{array}$ \\
\hline BLOCK & $\begin{array}{l}-0.003^{* * *} \\
(-2.84)\end{array}$ & $\begin{array}{l}-0.004 * * \\
(-2.50)\end{array}$ & $\begin{array}{l}0.002 * * * \\
(3.21)\end{array}$ & $\begin{array}{l}0.002 * * \\
(2.02)\end{array}$ \\
\hline BSize & $\begin{array}{l}-0.059 * * * \\
(-4.38)\end{array}$ & $\begin{array}{l}-0.069 * * * \\
(-3.80)\end{array}$ & $\begin{array}{l}0.043 * * * \\
(4.96)\end{array}$ & $\begin{array}{l}0.056 * * * \\
(4.89)\end{array}$ \\
\hline Directorships & $\begin{array}{l}0.027 * * * \\
(6.21)\end{array}$ & $\begin{array}{l}0.002 \\
(0.38)\end{array}$ & $\begin{array}{l}-0.018 * * * \\
(-6.23)\end{array}$ & $\begin{array}{l}-0.004 \\
(-1.06)\end{array}$ \\
\hline ICR & $\begin{array}{l}0.001 \\
(0.97)\end{array}$ & $\begin{array}{l}0.001 * * \\
(1.99)\end{array}$ & $\begin{array}{c}-0.000 \\
(-0.74)\end{array}$ & $\begin{array}{l}-0.001 * \\
(-1.86)\end{array}$ \\
\hline CASH & $\begin{array}{l}0.490 * * * \\
(4.41)\end{array}$ & $\begin{array}{l}0.506 * * * \\
(3.39)\end{array}$ & $\begin{array}{l}-1.861 * * * \\
(-26.13)\end{array}$ & $\begin{array}{l}-1.521 * * * \\
(-14.75)\end{array}$ \\
\hline Year effect (YR) & Yes & Yes & Yes & Yes \\
\hline Industry effect (IND) & Yes & No & Yes & No \\
\hline Firm effect & No & Yes & No & Yes \\
\hline Constant & $\begin{array}{l}-3.731 * * * \\
(-8.08)\end{array}$ & $\begin{array}{l}-0.066 \\
(-0.10)\end{array}$ & $\begin{array}{l}6.608 * * * \\
(22.38)\end{array}$ & $\begin{array}{l}3.233 * * * \\
(7.07)\end{array}$ \\
\hline Adj. $R^{2}$ & 0.353 & 0.215 & 0.370 & 0.231 \\
\hline Observations & 8875 & 8875 & 8820 & 8820 \\
\hline
\end{tabular}

This table presents the regression results on the effect of corporate governance quality and default risk using alternative control variables. ROA earnings before interest and taxes over total assets; CASH is cash over current liabilities; ICR is earnings before interest and taxes divided by interest paid; BLOCK is measured as a percentage of outstanding shares held by substantial shareholders; BSize is the number of directors in the board; Directorships is the average number of outside directorships held by the board. See Table 1 for definitions of other variables. Figures in parenthesis are the t-statistics. Standard errors are corrected based on one-way clustering by firm (e.g., Petersen, 2009). Superscripts $* * *, * *, *$ indicate statistical significance at $1 \%, 5 \%$, and $10 \%$ respectively.

\section{Internet Appendix IA3: Role of financial constraints}

Financial constrained firm is the one which has difficulty in accessing external finance due to extra cost and default occurs when the firm is unable to make interest and principal payment to the creditors. Considering this close linkage of financial constraints with default risk, we further explore does the effect of corporate governance on the default risk depend on whether a firm is financially constrained. In particular, this relation could be positive or at least nonnegative in financially constrained firms. To determine whether financial constraints influence the relation between corporate governance and the default risk, we interact corporate governance with variables that proxy for the degree to which a firm is financially constrained. The coefficients on the constraint proxies interacted with CG index represent the partial effect of corporate governance on default risk for financially constrained firms whereas the coefficient on CG index denotes the partial effect of corporate governance on default risk for financially unconstrained firms. 
A number of financial constraint proxies are available in literature (Liu and Mauer, 2011). It is argued that small firms are more vulnerable to capital market imperfections (Gertler and Gilchrist, 1994). Based on this argument, firm size can be used as a measure of financial constraint. Similarly, dividend payout is an indicator of costly external finance because low payout firms have insufficient internal cash flow to fund investments and thus have to rely on external sources (Fazzari et al., 1988).

Table IA.3 reports regression results in which we interact CG index with two different proxies of financial constraints: a dummy variable for whether a firm has low payouts (LowPayout) in Models 1-3 and a dummy variable for small firm size (SmallTA) in Models 4-6. We use the sample medians of total assets and dividend payout ratio to construct the dummy variables SmallTA and LowPayout, respectively. LowPayout is a dummy variable which takes the value ' 1 ' if the payouts is lower than the sample median, and ' 0 ' otherwise; SmallTA is a dummy variable which takes the value ' 1 ' if the firm size is lower than the sample median and ' 0 ' otherwise.

As can be seen in the table, the coefficients on the constraint proxies interacted with CG index are generally negative and statistically significant. However, the coefficients on CG index are generally positive and statistically significant. These results suggest that the significant inverse impact of corporate governance on default risk exists only for the financial unconstrained firms, suggesting that large and dividend paying firms are benefited more from the improvement in corporate governance quality."

Table IA.3: The joint effect of CGQ and financial constraints on default risk (H1)

\begin{tabular}{|c|c|c|c|c|c|c|}
\hline & \multicolumn{3}{|c|}{ Dividend Payout } & \multicolumn{3}{|l|}{ Firm size } \\
\hline & OLS & $\mathrm{FE}$ & $\mathrm{BE}$ & OLS & $\mathrm{FE}$ & $\mathrm{BE}$ \\
\hline & $(1)$ & $(2) \times$ & (3) & (4) & $(5)$ & $(6)$ \\
\hline \multirow[t]{2}{*}{ CG index } & $0.047 * * *$ & $0.072 * * *$ & $0.047 * * *$ & $0.103 * * *$ & $0.077 * * *$ & $0.103 * * *$ \\
\hline & $(2.65)$ & $(4.23)$ & $(4.62)$ & $(6.53)$ & $(7.36)$ & $(11.86)$ \\
\hline \multirow[t]{2}{*}{ LowPayout } & $-1.198 * * *$ & $-0.532 * * *$ & $-1.198 * * *$ & & & \\
\hline & $(-5.55)$ & $(-2.70)$ & $(-9.30)$ & & & \\
\hline \multirow[t]{2}{*}{ CG index*LowPayout } & $-0.047 * *$ & $-0.054 * * *$ & $-0.047 * * *$ & & & \\
\hline & $(-2.56)$ & $(-3.05)$ & $(-4.15)$ & & & \\
\hline \multirow[t]{2}{*}{ SmallTA } & & & & $-0.061 * * *$ & $-0.024 *$ & $-0.061 * * *$ \\
\hline & & & & $(-3.35)$ & $(-1.76)$ & $(-5.26)$ \\
\hline \multirow[t]{2}{*}{ CG index*SmallTA } & & & & $-0.617 * * *$ & -0.140 & $-0.617 * * *$ \\
\hline & & & & $(-3.33)$ & $(-1.07)$ & $(-5.27)$ \\
\hline Other controls & Yes & Yes & Yes & & & \\
\hline Industry effect (IND) & Yes & No & Yes & Yes & No & Yes \\
\hline Year effect & Yes & Yes & Yes & Yes & Yes & Yes \\
\hline Firm effect & No & Yes & No & No & Yes & No \\
\hline \multirow[t]{2}{*}{ Constant } & -1.252 & 0.986 & $-1.252 * * *$ & $3.421 * * *$ & $3.341 * * *$ & $3.421 * * *$ \\
\hline & $(-1.04)$ & $(1.55)$ & $(-3.00)$ & $(3.02)$ & $(21.32)$ & $(9.68)$ \\
\hline Adj. $R^{2}$ & 0.417 & 0.237 & 0.417 & 0.323 & 0.006 & 0.323 \\
\hline Observations & 8851 & 8851 & 8851 & 8851 & 8851 & 8851 \\
\hline
\end{tabular}

This table presents the regression results (using OLS, FE, and BE methods) on the interaction effect of corporate governance quality and financial constraints (LowPayout and SmallTA) on default risk. LowPayout is a dummy variable which takes the value ' 1 ' if the payouts is lower than the sample median, and ' 0 ' otherwise; SmallTA is a dummy variable which takes the value ' 1 ' if the firm size is lower than the sample median, and ' 0 ' otherwise; See Table 3.1 for variable definitions. Figures in parenthesis are the t-statistics. Standard errors are corrected based on one-way clustering by firm (e.g., Petersen, 2009). Superscripts ***, **, * indicate statistical significance at $1 \%, 5 \%$, and $10 \%$ respectively. 


\section{Highlights}

- Our study contributes to the ongoing literature debate: Does corporate governance reduce default risk in Australia?

- We show that the corporate governance is significantly and negatively associated with the default risk even after controlling for endogeneity bias.

- We find that the inverse effect of corporate governance on default risk is stronger for high growth firms.

- We also document that the corporate governance affects default risk through the channel of information asymmetry as measured by stock liquidity. 


\section{Accepted Manuscript}

Does corporate governance quality affect default risk? The role of growth opportunities and stock liquidity

Searat Ali, Benjamin Liu, Jen Je Su

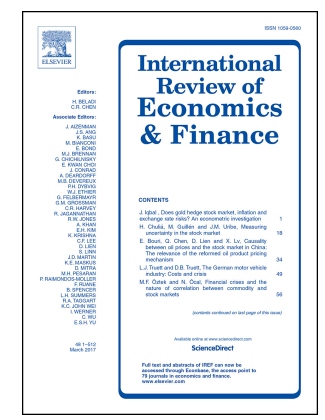

PII: S1059-0560(17)30755-4

DOI: $\quad$ 10.1016/j.iref.2018.05.003

Reference: REVECO 1638

To appear in: International Review of Economics and Finance

Received Date: 11 October 2017

Revised Date: 28 April 2018

Accepted Date: 3 May 2018

Please cite this article as: Ali S., Liu B. \& Su J.J., Does corporate governance quality affect default risk? The role of growth opportunities and stock liquidity, International Review of Economics and Finance (2018), doi: 10.1016/j.iref.2018.05.003.

This is a PDF file of an unedited manuscript that has been accepted for publication. As a service to our customers we are providing this early version of the manuscript. The manuscript will undergo copyediting, typesetting, and review of the resulting proof before it is published in its final form. Please note that during the production process errors may be discovered which could affect the content, and all legal disclaimers that apply to the journal pertain. 